\title{
Introduction to Microarray-Based Detection Methods
}

Jacques Schrenzel, Tanja Kostic, Levente Bodrossy, and Patrice Francois

\section{1}

Introduction to Microarray Technology

Microarrays consist of an orderly arrangement of probes (oligonucleotides, DNA fragments, proteins, sugars or lectins) attached to a solid surface. The main advantages of microarray technology are high throughput, parallelism, miniaturization, speed and automation. Despite the fact that microarray analysis is a relatively novel technology, with the publication of the first microarray studies in 1995 $[101,152]$, it is now broadly applied and the milestone of nearly 5000 published microarray papers was recorded in 2004 [80]. The scientific and technological background discussed here will be limited to DNA microarrays, excluding the new evolving fields of protein microarrays and glycomics [140].

Analogous to antigen-antibody interactions on immunoarrays, DNA microarrays rely on sequence complementarity of the two strands. They put in practice the fundamentals of complementary base-pairing (hybridization) that were first described by Ed Southern [162]. In general, the strategy of microarray hybridization is reversed to that of a standard dot-blot, leading to recurring confusion in the nomenclature. Therefore, it has been suggested to describe tethered nucleic acid as the probe and free nucleic acid as the target [134].

Earlier studies on duplex melting and reformation, carried out on DNA solutions, have provided the basic knowledge about the reaction kinetics. Furthermore, a method for computational determination of the melting point as a function of nucleic acid composition and salt concentration was established [6, 148, 149]. Much of the pioneering work can be linked to the use of nitrocellulose membranes [69], dot-blots [84] and Southern blots [162]. Development of cDNA or oligonucleotide arrays was possible by combined innovations in micro-engineering, molecular biology [33, 120, 123, 156, 163, 164] and bioinformatics [59]. The real breakthrough in microarray technology was initiated by two key innovations: the use of non-porous solid supports (such as glass and silicon) and the development of methods for highdensity synthesis of oligonucleotides directly onto the microarray surface [59]. 
Microarrays have demonstrated their applicability for a broad variety of applications such as cell differentiation [170], whole-genome expression analysis [67, 152], cancer research [5, 71, 131], comparative genome hybridization (CGH) [146], drug discovery [39], vaccine development [72] or single nucleotide polymorphism (SNP) analysis [56].

Technology transfer to diagnostic applications is therefore very appealing [3, 112, 196]. Reports have already shown that oligonucleotide microarrays can enable bacterial detection utilizing conserved bacterial genes [158], species identification [189] as well as genotyping of bacterial pathogens, by using large sets of discriminative epidemiological markers [32, 36, 70, 183, 198]. Detection of genetically encoded virulence or antimicrobial resistance determinants $[17,36,112,176]$ may also afford a major benefit for selection of an adequate chemotherapy.

Current limitations for routine implementation of microarrays to detect DNA signatures are, initially, their high manufacturing costs and the requirement for large amounts of nucleic acid targets. Availability of large amounts of nucleic acid targets requires either a large volume of bacterial culture (biological amplification) or target amplification [122, 139]. Additional technical achievements in signal amplification methods [60] and novel optical techniques [57, 128] can already improve target detection to the femtomole range.

The development of microarray-based bacterial identification starting directly from the biological sample, without any enzymatic target amplification, is an important objective [168]. This procedure would significantly reduce the turnaround time and overcome enzymatic-induced signal alterations or biases $[16,197]$.

\section{2}

\section{Technical Aspects of Microarray Technology}

The development of a new microarray platform requires consideration of many different features, most of them being co-dependent (see Figure 1.1). Different approaches have been reported, each of them exhibiting certain advantages and limitations. A summary of the most important technological features will be given to introduce the specific platforms in association with the intended experimental applications.

\subsection{1}

\section{Probes}

The nature of the probe used is related to the experimental question. In general it can be distinguished between genome fragments, polymerase chain reaction (PCR) products and oligonucleotide probes. Application potential as well as advantages and limitations of each probe type will be described briefly. An additional summary of different probe types is presented in Table 1.1 (see p. 4). 


\section{Biological question}

what are we trying to learn

from the experiment

\section{Data analysis \\ image quantification \\ normalization \\ analysis}

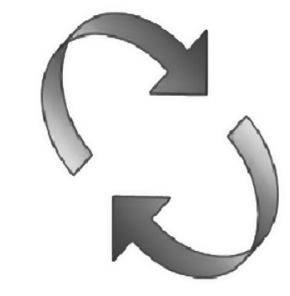

Biochemical reaction

hybridization and washing conditions stringency

\author{
Microarray fabrication \\ probe preparation/design \\ microarray format \\ (substrates, buffers, ...)
}

Figure 1.1 Elements of the microarray experiment (adapted from [204]). Starting (clockwise) from a biological question, the process leads ultimately to data analysis and new knowledge, enabling us to address and refine the biological question.

\subsubsection{Genome Fragments}

The use of entire bacterial or community genomes (suitably fragmented) as probes was first employed for the reverse sample genome probing technique [184]. The same principle was later applied for community genome arrays [10, 124]. The major problem related to such microarray platforms is the huge complexity of the system.

\subsubsection{PCR Products}

PCR products used as probes for microarray fabrication are mostly amplified inserts of the clone libraries. Different types of clone libraries can be used as a template for microarray fabrication (cDNA libraries, suppression subtractive hybridization ( $\mathrm{SSH}$ ) libraries, shotgun libraries, open reading frame (ORF) libraries, etc.). Microarrays utilizing PCR products are used for gene expression analysis $[68,97,124,152,167,199]$. Furthermore, PCR products can be used as probes for the functional gene arrays $[31,191]$. The inappropriate labeling of a substantial fraction of the PCR products $(1-5 \%)$ can lead to poorly controlled microarrays, even when originating from prestigious research centers or commercial entities [89]. The IMAGE consortium (Integrated Molecular Analysis of Genomes and their Expression) revealed that, after resequencing, only $62 \%$ of 1189 cDNAs were pure and correct.

\subsubsection{Oligonucleotide Probes}

Oligonucleotide microarrays provide a flexible design, and are considered more reliable in terms of sensitivity and specificity [15, 18, 92, 94]. Differing from the previously described PCR probes, oligonucleotide probes are typically designed with a predefined specificity. Generic or universal oligonucleotide probes form a distinct group of oligonucleotide probes that are predefined only by length (and not by specificity). In this case a probe set is designed to contain all possible 
$4 \mid 1$ Introduction to Microarray-Based Detection Methods

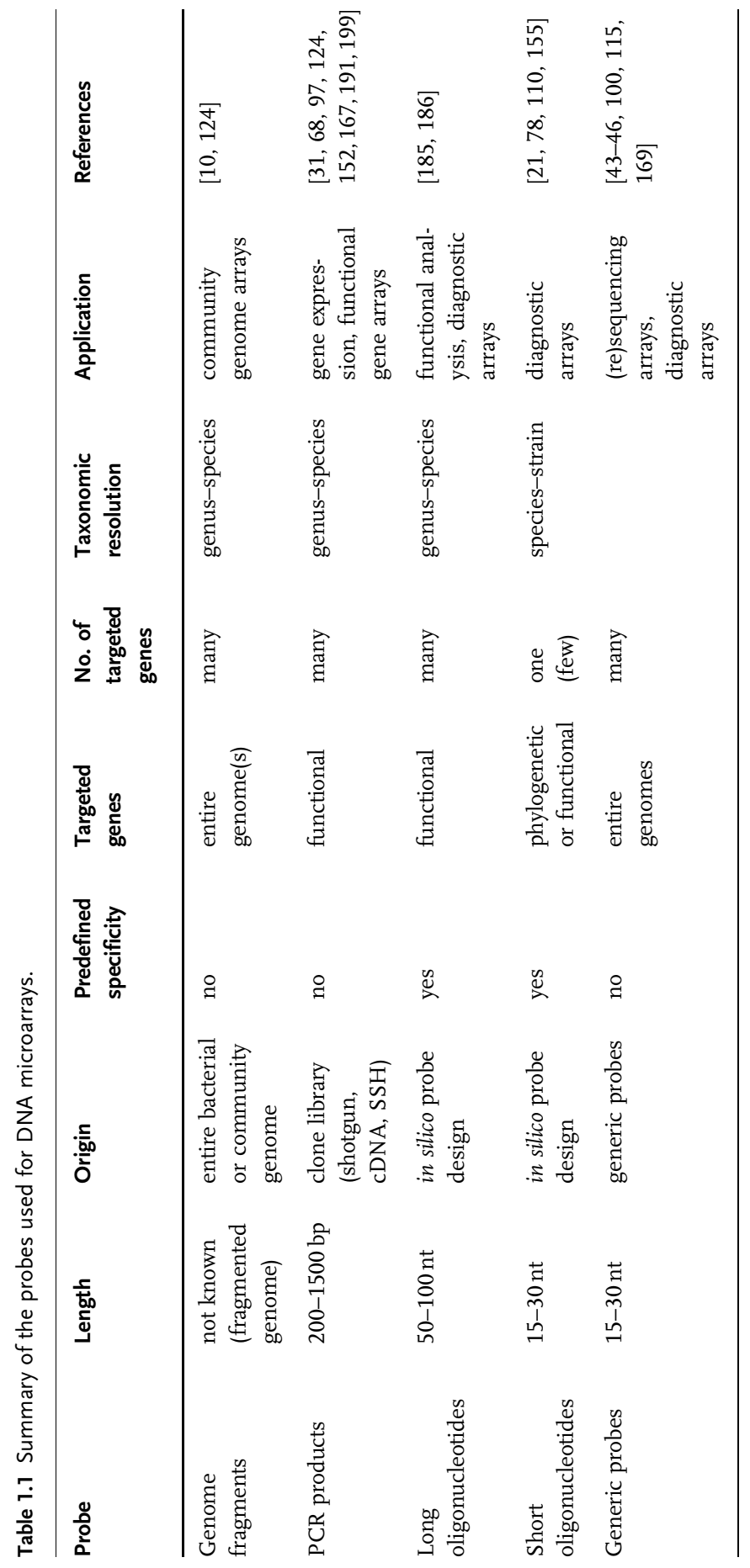


sequence permutations of a given length. Generic arrays have been used to study large-scale hybridization behavior [163] or for solid-state nucleic acid sequencing [43-46, 100, 115, 169].

Two main features influence probe specificity: probe length and the degree of conservation of the marker gene. In general, probe design is carried out in silico using different software tools (e.g. ARB [113] or OligoCheck [35]) and is based on a sequence database of the targeted marker gene. The extent and quality of the sequence database has a major effect on probe quality.

The general criteria that need to be considered during probe design are the required probe specificity and uniformity of the probe set regarding hybridization behavior. In silico approaches allow for partial prediction of the hybridization behavior of designed probes. However, it has become clear that the simple notion that short oligonucleotides with a mismatch (MM) should hybridize less efficiently than perfect-match (PM) probes is not always applicable [137]. It has been demonstrated that the hybridization intensity of MM probes can depend on the nucleotide type (i.e. A, C, G or T) and position of the MM relative to the termini [178, 179], and that some MM probes yield even higher signal intensities with the target than those of corresponding PM probes [125]. Defined mismatches are more difficult to detect (e.g. GG or GT), as well as mismatches that reside in a context (GC-rich domain). Even well-designed probes can display differences in maximal hybridization capacity of 2 orders of magnitude under different hybridization conditions [22] and thus it is difficult to find one set of conditions that is optimal for all probes on an array [85, 178]. Factors affecting duplex formation on DNA microarrays include probe density, microarray surface composition, spacer length and the stabilities of oligonucleotidetarget duplexes, intra- and intermolecular self-structures, and RNA secondary structures [75, 121, 133].

More generally, there is a lack of a simple relationship between hybridizations of probe-target duplexes as inferred from signal intensity values and in silico predictions based on Gibbs free energies [137]. This does not apply as strictly for highdensity microarrays where the high level of redundancy accounts for the specificity of the signals nor for long oligonucleotide microarrays where inter-allele distinction is not required. In any case, a thorough wet-lab validation with a set of reference strains or clones is warranted, as for the implementation of any other molecular tool [35].

Long Oligonucleotides The main advantages of long oligonucleotides (over 50 nucleotides in length) are high target binding capacity and irreversible hybridization kinetics. These features allow for enhanced detection sensitivity. However, the threshold for the differentiation is at $85-90 \%$ sequence similarity, resulting in reduced specificity. This can be compensated by the host specificity of the targeted genes. Due to their high sensitivity, long oligonucleotide microarrays are typically used in combination with universal amplification techniques or without any amplification, allowing the researcher to target an unlimited number of different genes [174]. Long oligonucleotide microarrays have been used for the detection of viruses [186] and pathogens [185]. 
1 Introduction to Microarray-Based Detection Methods

\begin{tabular}{|c|c|c|}
\hline & Long & Short \\
\hline Typical length & $>50$ & $15-30$ \\
\hline $\begin{array}{l}\text { Optimal hybridization } \\
\text { conditions }\end{array}$ & $1 \mathrm{M} \mathrm{Na}^{+}, 65-70^{\circ} \mathrm{C}$, no formamide & $1 \mathrm{M} \mathrm{Na}^{+}, 40-60^{\circ} \mathrm{C}$, no formamide \\
\hline \multirow[t]{3}{*}{$\begin{array}{l}\text { Optimal wash conditions } \\
\text { hybridization kinetics }\end{array}$} & $\begin{array}{l}0.015 \mathrm{M} \mathrm{Na}^{+}, 65^{\circ} \mathrm{C} \\
\text { Irreversible }\end{array}$ & $\begin{array}{l}0.015 \mathrm{M} \mathrm{Na}^{+}, 20-22{ }^{\circ} \mathrm{C} \\
\text { Reversible }\end{array}$ \\
\hline & $\begin{array}{c}\text { Long oligos } \\
\uparrow \quad \text { irreversible hybridization }\end{array}$ & $\begin{array}{c}\text { Short oligos } \\
+\quad \text { reversible hybridization }\end{array}$ \\
\hline & $\mathrm{T}$ & $\mathrm{T}$ \\
\hline $\begin{array}{l}\text { Melting temperature is at } \\
\text { which... }\end{array}$ & $\begin{array}{l}50 \% \text { of the nucleotides are unbound } \\
\left(T_{m} 8\right)\end{array}$ & $\begin{array}{l}50 \% \text { of the strands are single } \\
\text { stranded }\left(T_{m}\right)\end{array}$ \\
\hline Dissociation is ... & $\begin{array}{l}\text { intramolecular process? } \\
T_{m} \text { is concentration independent }\end{array}$ & $\begin{array}{l}\text { intermolecular process? } \\
T_{m} \text { is concentration dependent }\end{array}$ \\
\hline Target used for hybridization... & $\begin{array}{l}\text {...can be very complex, no specific } \\
\text { amplification needed. }\end{array}$ & $\begin{array}{l}\text {...has to be restricted to one or a few } \\
\text { genes, PCR amplification required }\end{array}$ \\
\hline
\end{tabular}

Figure 1.2 Comparison of long versus short oligonucleotide probes.

Short Oligonucleotides Short oligonucleotide (15-30mer) microarrays are more precise at the detection of shorter nucleotide polymorphisms, including single nucleotide differences under optimized hybridization conditions. On the downside, short oligoarrays frequently require a larger number of probes for reliable diagnostics. Reversible hybridization kinetics and lower target binding capacity (in comparison to long oligonucleotides) are responsible for somewhat limited detection sensitivity (Figure 1.2). Short oligonucleotide are widely used for both environmental and diagnostic microbial diagnostic microarrays (MDMs) [21, 78, 110, 155].

\section{2 .2}

\section{Substrates for Printing}

The choice of the substrate for microarray printing depends primarily on the nature of the probes. An important factor to be taken into consideration is the effect of steric hindrance on the hybridization efficiency [21]. This may be a considerable problem in the case of short oligonucleotide probes and therefore such probes are generally appended to spacer molecules. Further important parameters to be considered during fabrication of the microarray are the probe concentration, spotting buffer and surface blocking strategies. Most of these features have been discussed thoroughly in the literature [79, 98, 172, 200]. The most widely used microarray format is a planar glass slide $(1 \times 3$ in.). Slides for microarray printing are usually coated with different active surfaces that facilitate deposition of nucleic acids. An overview of the more commonly used substrates and their applications will be given below. A list of commercially available surface chemistries is given in Table 1.2. 


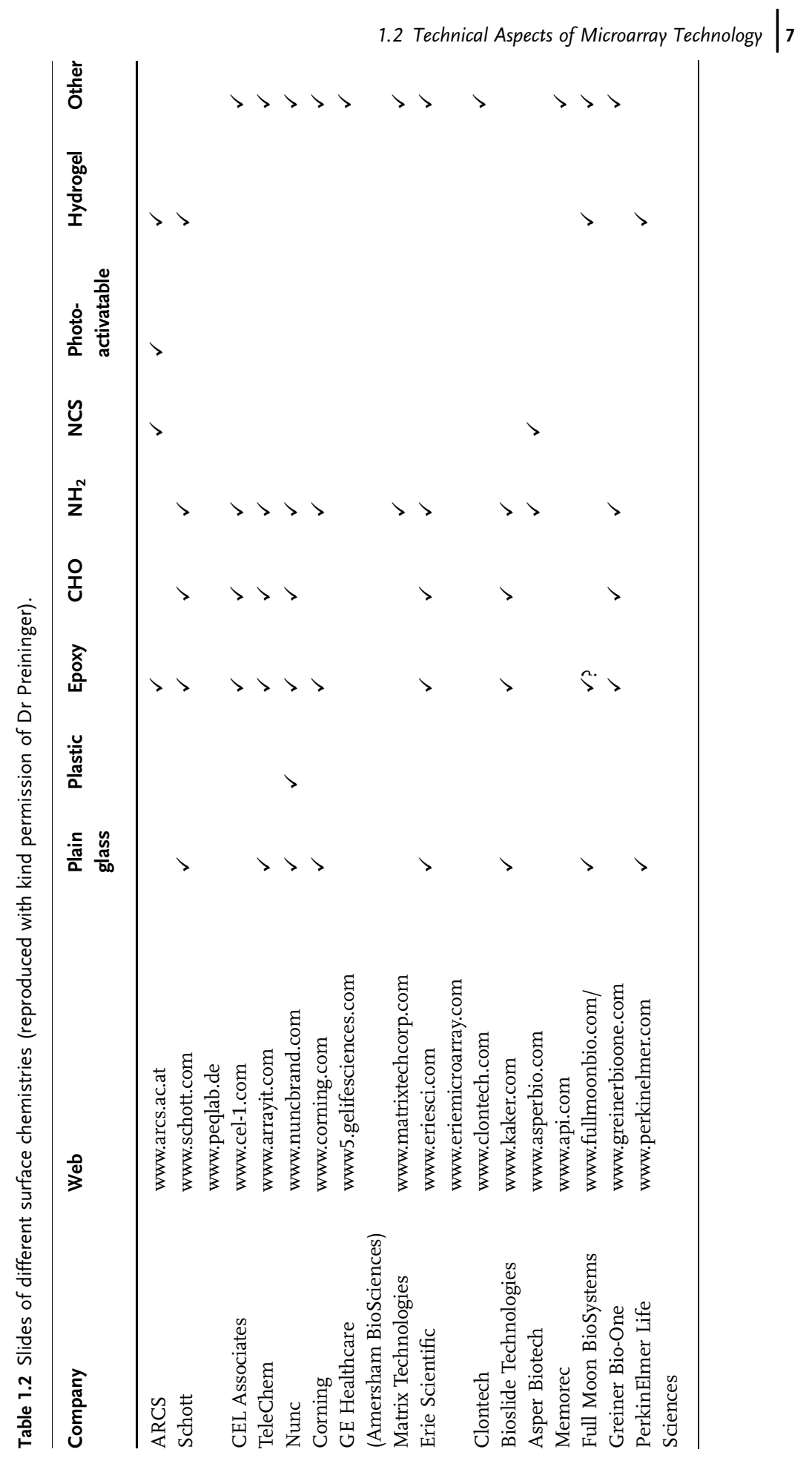


$8 \mid 1$ Introduction to Microarray-Based Detection Methods

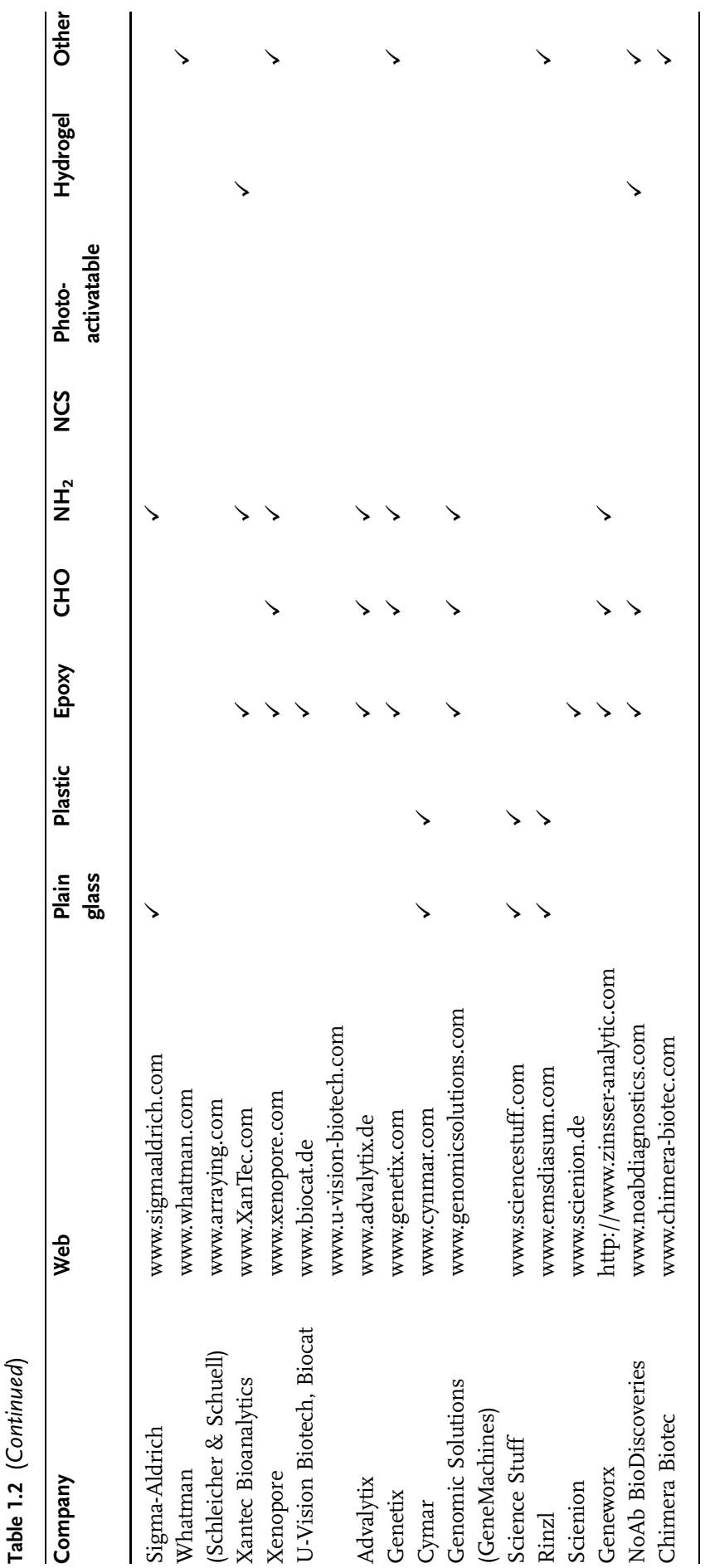




\subsubsection{Slides with Poly-L-lysine Coating}

The binding of DNA fragments to poly-L-lysine involves charge interactions that can be converted to covalent bonding by baking or ultraviolet (UV) cross-linking. Advantages of poly-L-lysine surfaces are low background and good signal intensities. The main disadvantage is low temperature resistance that can lead to the damage of the surface during denaturation or hybridization at higher temperature. PolyL-lysine-coated slides have been successfully used for the binding of PCR products [41, 152, 199] and short oligonucleotides [172].

\subsubsection{Slides with Amino Silane Coating}

Amino silane surface chemistry allows for electrostatic interactions between the amino groups of the silane (positively charged at neutral $\mathrm{pH}$ ) and negatively charged phosphodiester backbone of the DNA. This interaction can be additionally stabilized by UV cross-linking. Amino silane coating demonstrates enhanced resistance towards high temperatures. However, somewhat higher background signals may occur when low-quality coatings are used. Substrates based on amino silane surface chemistry are widely used for deposition of PCR products [40, 68, 141, 145, 167, 175].

\subsubsection{Slides with Aldehyde Coating}

Covalent binding between aldehyde groups and DNA fragments can be facilitated, either through a $5^{\prime}$-amino linker on chemically modified DNA fragments or through aromatic amines of nucleotides. Probes with a $5^{\prime}$-amino group bind more efficiently than native DNA fragments. Furthermore, coupling via a $5^{\prime}$-amino group is directional, allowing for the defined orientation of the probes on the microarray. In general, slides with aldehyde coating are characterized by high binding capacity and low background. Aldehyde-coated slides are mostly used for short oligonucleotide microarrays [21, 109].

\subsubsection{Slides with Epoxy Coating}

Similarly to aldehyde-coated slides, epoxy-coated substrates also allow for the covalent binding utilizing amino groups of the DNA fragments. Epoxy-coated slides have been used for the deposition of PCR products [31], and short [11] and long [187] oligonucleotides.

\subsubsection{Proprietary Surface Chemistries}

Finally, it is worth mentioning that the array surface of various commercial microarrays can display very different properties (e.g. a highly hydrophobic surface on the Agilent SurePrint technology (www.agilent.com) due to proprietary surface chemistry). This leads to the use of specific hybridization and washing buffers adapted to the surface chemistry.

\subsubsection{Probe Spacers}

To reduce the effect of steric interference (steric hindrance and surface electrostatic forces) $[156,180]$ on hybridization of targets to planar surfaces (e.g. glass and silicon), spacer molecules with a length of more than $50 \AA$ can be used to physically separate 
the probes from the microchip surface $[130,156]$. These are typically $\mathrm{C}_{6}-\mathrm{C}_{12}$ alkane spacers and/or 5-15 thymidine or adenine residues added to the tethered end of the oligo probe $[7,24,61,201]$.

\section{2 .3}

\section{Targets for Microarray Analysis}

Targets used for microarray analysis are typically fluorescently labeled nucleic acid derivatives. Two basic types of targets can be distinguished: those derived from RNA and those derived from DNA templates. Selection of nucleic acids used as a template for target preparation is primarily dependent on the experimental question. Gene expression studies use mRNA-based targets, whereas microbial diagnostic arrays employ primarily DNA-based targets or rRNA targets that are more abundant. The parallel analysis of mRNA- and DNA-based targets provides a complex picture correlating presence and activity [23].

\subsubsection{Target Amplifications and Sensitivity Issues}

In general, targets used for short oligonucleotide diagnostic microarrays are previously PCR-amplified. PCR amplification ensures enrichment of the targeted gene(s) and therefore increases the sensitivity of microarray detection, but also introduces an inherent PCR bias [185]. Long oligonucleotide probes exhibit higher target binding capacity and therefore allow hybridization with highly complex target mixes (i.e. unamplified environmental DNA, a native mixture of mRNA from an organism or the products of universal, whole-genome amplification methods). The main advantage of the latter targets is that they represent the entire gene pool to be studied, without reduction of its complexity.

Thus, the potential of DNA microarray-based microbial screening and diagnostic technologies is currently limited by front-end target-specific nucleic acid detection. The presence of an ubiquitous poly-adenylated tail at the $3^{\prime}$-end of eukaryotic messenger RNAs offers the possibility to convert minute amounts of RNA to micrograms of labeled material, with minimal effects on the respective abundance of the mRNA mixture $[8,139]$. Prokaryotic RNAs are not poly-adenylated and are thus more challenging to work with when starting material is scarce. In such cases, the use of generic primers able to amplify parts of the targeted gene is often required [7, 144], but the universality of such primers is questionable (false-negative signals are not rare [7]). Other options include intact or even degraded RNA amplification using T3-coupled random primers [193] or a limited set of genome-derived cognate primers [205].

The interested reader is referred to two recent publications that have analyzed and validated different target amplification strategies before array hybridization $[62,185]$. Vora et al. investigated four front-end amplification strategies: random primed, isothermal Klenow fragment-based, Ф29 DNA polymerase-based and multiplex PCR. Their results underscore the feasibility of using random amplification approaches and begin to systematically address the versatility of these approaches for unbiased pathogen detection from environmental sources [165]. Francois et al. compared 
commercially available amplification methods such as MessageAmp or GenomiPhi. They showed that this type of enzyme represents an interesting alternative of moderate cost for transcriptomic studies. Such amplifications permitted the authors to obtain significant amounts of nucleic acids, sufficient to perform microarray studies even when starting with a few tens of nanograms of material. Importantly, these methods showed exquisite reproducibility, even considering data before normalization, which is the major requirement for their utilization in transcriptomic studies [188]. Finally, these nucleic amplification methods can be coupled to signal amplification (see, e.g. [27]) and/or array-based methods for improving detection sensitivity.

\subsubsection{Labeling of the Targets}

Fluorescently labeled targets are in general prepared using one of the many commercially available kits [114] or following standardized labeling protocols [21]. Incorporation of the fluorescently labeled nucleotides occurs during enzymatic amplification of the nucleic acids (e.g. PCR amplification, in vitro transcription, reverse transcription, random DNA amplification). Alternatively, modified nucleotides (i.e. amino-allyl nucleotides) can be incorporated in the target followed by subsequent coupling with fluorescent dye esters.

\subsubsection{Hybridization and Wash Conditions}

Hybridization specificity is of paramount importance, especially when one has to differentiate targets from non-targets or to discriminate closely related DNA or RNA sequences that may possibly differ by only a single base pair. Probes on the microarray are subjected to the same hybridization and washing procedures (e.g. buffers, salt concentrations, and temperature). Strategies to overcome problems arising thereof include the acquisition of melting curves for every individual probe [104]; the careful design of probes with similar predicted hybridization properties (usually combined with the application of two to three probes per targeted group) $[24,147,201]$; the addition of tetramethylammonium chloride that equalizes the melting temperature of different probes by stabilizing the AT base pairs; composition of the hybridization solution [120]; or the use of highly redundant probe sets with multiple probes to target each specific group of microorganisms [189].

Secondary structure formation within the targets can reduce the binding constant of a specific probe by as much as $10^{5}-10^{6}$ times [96], leading to an increase in falsenegative signals and a decrease in hybridization specificity $[9,164]$. Several methods have been suggested to alleviate this problem, such as the use of helper oligonucleotides [130] and a two-probe proximal chaperon detection system [158] to mitigate the effects of target secondary structure hindrances, an appropriate labeling method [63], and a protocol to achieve optimized target lengths [126, 164, 197]. Since long targets can form secondary and tertiary structures that hinder efficient probe-target duplex formation, the sizes of the target molecule and its amplicon are often reduced via chemical, enzymatic or thermal fragmentation methods [24, 87, 104, 126, 138, 158]. Liu et al. have recently elegantly reviewed these issues and experimentally demonstrated that microarray hybridizations with short rRNA fragments were more 
dependent on target sequence than on the competition between probe-target interaction and RNA self-folding [103].

Hybridization with short gene fragments increases the potential for the accumulation of background signal from non-specific hybridization events. In order to circumvent this negative target effect an alternative protocol - sequence-specific end-labeling of oligonucleotides - was developed (see Chapter 3; Kostić et al., [206] and Ref. [145]). In this approach, targets are complementary to oligonucleotide probes on the array, and the labeling is performed by incorporating singlelabeled dideoxynucleotide in the presence of the targeted PCR product. This methods ensures both high specificity and sensitivity, however, it is still affected by PCR bias.

\subsection{4}

\section{Classical Commercially Available Microarray Formats}

All platforms share the common attribute that a sensor detects a signal from target sequences hybridized to immobilized nucleotidic probes. The intensity of this signal provides a measure of the amount of bound nucleic acid from a sample [137]. Schematically, we have divided this section into spotted and in situ synthesized arrays. Section 1.2.5 focuses on alternative platforms that provide improved detection sensitivities.

\subsubsection{Spotting Approaches}

Currently, up to 50000 gene fragments or oligonucleotides can be spotted onto a single microscope slide using robotic technology. The advantages of this technology are flexibility in the design of the array, the relative ease of production and its relatively low cost. Multiple identical microarrays can be robotically printed in batches of over 100 in a single run. Most of the cost in printing such arrays is associated with the synthesis of oligonucleotide probes or primer pairs required for the amplification of the probe gene fragments [42]. Here, we briefly review various commercially available microarray formats.

Operon The Qiagen Operon format (www.operon.com) uses optimized 70mer oligonucleotides to represent each gene in a given genome. Each 70 mer probe is designed to have optimal specificity for its target gene and is melting-temperature normalized. This approach provides a reduction in cross-hybridization and an increase in the differentiation of overlapping genes or highly homologous regions. Theoretically, mutant alleles could be detected using such oligonucleotide microarrays owing to the shorter probe size compared to PCR product-based microarrays [42].

\subsubsection{In Situ Synthesis}

In situ synthesis allows higher yields, lower chip-to-chip variation, as well as higher probe densities. These methods also permit the manufacture of true 'random access' arrays [164]. Manufacturing techniques include photolithographic masks to control 
chemical activation by photodeprotection steps [59, 100], ink-jet deposition [81, 166], as well as physical barriers allowing for sequential flooding of precursors [120].

Affymetrix Oligonucleotide probes are not deposited on Affymetrix microarrays (www.affymetrix.com), but are directly synthesized on the surface. The company has coupled photochemical deprotection to solid-phase DNA synthesis by adapting techniques from the semiconductor industry $[100,105,129]$. The main advantage of this approach is very high probe density (over 500000 probes can be deposited on a surface of $1.6 \mathrm{~cm}^{2}$ ). Limitations are high price, low flexibility and lack of properly validated probe sets. Therefore, in order to ensure the specificity of detection, applications of the Affymetrix platform require multiple probes to monitor single targets, relying on empirical algorithms [30].

NimbleGen Recent technical developments, such as Nimblegen's micromirror device (www.nimblegen.com), facilitate maskless photoreactive synthesis of oligonucleotide probes, and currently permit the simultaneous deposition and analysis of as many as nearly 800000 probes on one array platform [4]. Such probe density now permits detailed CGH for detecting small deletion changes in the studied genome. However, insertions of genes compared with the sequenced reference strain cannot be detected by CGH DNA microarray analyses. This problem can be alleviated by adding non-redundant amplified sequences from several closely related bacteria to the array, once new genetic information is available [26, 27, 34, 135].

Agilent A more versatile, but still essentially mechanical, method for producing DNA arrays is to use the print heads out of commercial piezoelectric ink-jet printers to deliver reagents to individual spots on the array [13,19,161]. A piezoelectric ink-jet head consists of a small reservoir with an inlet port and a nozzle at the other end. When a voltage is applied to the crystal, it contracts laterally thus deflecting the diaphragm and ejecting a small drop of fluid from the nozzle. Such devices are inexpensive and can deliver drops with volumes of tens of picoliters at rates of thousands of drops per second. In conjunction with a computer-controlled $X Y$ stepping stage to position the array with respect to the ink-jet nozzles, it is possible to deliver different reagents to different spots on the array. Arrays of approximately 250000 spots can be addressed in a few minutes with each spot receiving one drop of reagent. Agilent has developed a flexible method for microarray production, centered around an in situ oligonucleotide synthesis method in which the ink-jet printing process is modified to accommodate delivery of phosphoramidites to directed locations on a glass surface [19]. Achieving high density with the ink-jet approach requires one more trick. Two drops of liquid applied too closely together on a surface will tend to spread into each other and mix. For 40-pl drops the minimal center-to-center spacing is about $600 \mu \mathrm{m}$. This limits the array density achievable with the ink-jet method. One way around this is to engineer patterns in the surface chemistry of the array to produce spots of a relatively hydrophilic character surrounded by hydrophobic barriers [19, 161]. Design flexibility and high densities constitute the two major advantages of this technique that can generate arrays at moderate costs. 
CombiMatrix CombiMatrix's technology (www.combimatrix.com) is a specially modified semiconductor adapted for biological applications. These integrated circuits contain arrays of microelectrodes that are individually addressable using embedded logic circuitry on the chip. Placed in a specially designed fluidic chamber, the chip digitally directs the molecular assembly of biopolymers in response to a digital command.

Under a controlled process, each microelectrode is addressed to selectively generate chemical reagents by means of an electrochemical reaction. These chemical reagents facilitate the in situ synthesis of complex molecules such as DNA oligonucleotides. The parallel process drastically reduces the cost and time of synthesizing hundreds or thousands of different molecules. Currently, this technology is able to produce arrays with approximately 45000 features.

\section{2 .5}

\section{Alternative Methods for Improving Microarray-Based Detection Sensitivity}

Most microarray applications are limited by the starting amounts of nucleic acids to be studied. In other words, detection sensitivity is a major limitation of microarraybased approaches that has to be compensated by several enzymatic steps for target amplification and/or labeling.

The followings sections illustrate various array-based methods that can also improve detection sensitivity, independently from any target or signal amplification.

\subsubsection{Resonance-Light Scattering (RLS)}

New optical techniques are now available for microarray detection $[57,128]$ that provide sensitivities high enough to detect femtomolar amounts of targets. Francois et al. [60] nicely illustrated the improvements in detection sensitivity that can be achieved with different optical detection methods when using direct non-enzymatic labeling of bacterial nucleic acids. Microarrays detected by RLS (Genicon, Invitrogen, Carlsbad, CA, USA) offer short turnaround times and exquisite sensitivity. Interestingly, the labeling and detection schemes offer an affordable alternative at a reasonable cost to the expensive fluorescence-based methods. The principle of RLS is the following: when a suspension of nano-sized gold or silver particles is illuminated with a fine beam of white light, the scattered light has a clear (not cloudy) color that depends on composition and particle size. This scattered light can be used as the signal for ultrasensitive analyte detection [127].

\subsubsection{Planar-Waveguide Technology (PWT)}

Figure 1.3 (see p. 16) depicts PWT technology-based microarrays. A 150-nm to 300-nm thin metallic oxide film (green) with a high refractive index (e.g. $\mathrm{Ta}_{2} \mathrm{O}_{5}$ or $\mathrm{TiO}_{2}$ ) is deposited on a transparent support (grey) with lower refractive index (e.g. glass or polymer). A parallel laser light beam (red) is coupled into the wave-guiding film by a diffractive grating that is etched into the substrate. The light propagates within this film and creates a strong evanescent field perpendicular to the direction of laser propagation into the adjacent medium [48]. The field strength decays exponentially 
with the distance from the waveguide surface and its penetration depth is limited to about $400 \mathrm{~nm}$ (large orange arrow). This effect results in the selective excitation of fluorophore molecules located at or near the surface of the waveguide (red circles). For microarray applications, specific capture probes or recognition elements are immobilized on the waveguide surface. Upon fluorescence excitation by the evanescent field, excitation and detection of fluorophores by a CCD camera is restricted to the sensing surface, whilst signals from unbound molecules in the bulk solution (blue) are not detected. This yields a significant increase in the signal/noise ratio compared to conventional optical detection methods [61]. PWT microarrays are also commercially available (e.g. Zeptosens; www.zeptosens.com).

\subsubsection{Liquid Arrays}

The Luminex (www.luminexcorp.com) suspension array is simply a transfer of the microarray format from a glass slide to a high-throughput and efficient bead format. With this type of assay, the DNA probes (e.g. oligonucleotides) are attached to 5.6-nm polystyrene microspheres ('beads') containing an internal fluorescent dye. Each probe is assigned to a particular bead set containing a unique mixture of fluorescent dyes, or 'spectral address'. Bead sets coupled to the probes of interest are then mixed together in the wells of a 96-well microtiter plate, allowing many different probes to be analyzed simultaneously. Target DNA molecules are labeled with a different and spectrally distinct fluorescent dye and hybridized to the probes on the beads. Beads with the hybridized targets are then separated and quantified using a two-laser flow cytometer. The unique internal color of the bead is read by one laser and serves to identify which probe is present on the bead. The second laser measures the fluorescent signal of the reporter dye present on the labeled target DNA and allows one to assess the strength of the hybridization between the target DNA and the probe. As this technology allows up to 100 different probes to be analyzed in a single well of a 96-well plate, it promises to make microarray subtyping faster and less expensive. The established suspension array protocol requires that relatively short PCR products be used as targets [47].

Microsphere-based fiber-optic arrays (Illumina; www.illumina.com) provide many advantages over other array-based methods [2]: higher sensor packing density, smaller assay sample volumes, increased array reusability, flexible array design, and reduced false-positives and false-negatives [50]. Previous work has demonstrated that the microsphere-based fiber-optic array can detect as few as 600 target DNA molecules and is sensitive enough to discriminate a single-base mismatch from a perfect match [49, 51].

\subsubsection{Three-Dimensional Microarray Formats}

Three-dimensional microarray formats offer the option to record hybridization and dissociation events in real time. This enables rapid establishment of the melting curves for all probes on the microarray, facilitating development of validated probe sets. Three-dimensional microarray systems include gel-pads [73, 104, 136], flow-through systems such as PamGene (www.pamgene.com) [192] or MetriGenix (www.metrigenix.com) [88]. 


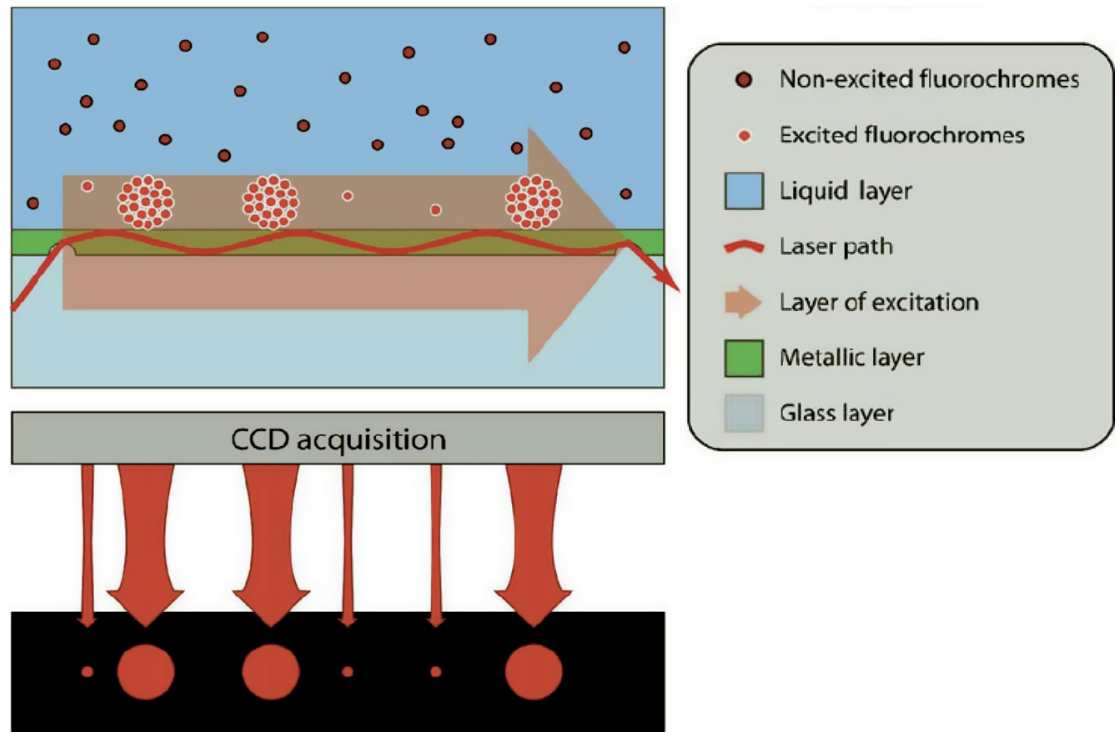

Figure 1.3 Schematic representation of PWT technology-based microarrays (from [61]).

\subsection{6}

\section{Marker Genes Used on MDMs}

Microarrays employing long oligonucleotide probes or gene fragments can target an unlimited number of different genes. Short oligoarrays, on the other hand, depend on PCR amplification to reduce target complexity to a level compatible with the sensitivity of the probes. They are thus usually limited to a small number of marker genes (typically between one and 10). Marker genes used for phylogenetic analysis and the development of short oligonucleotide MDMs need to fulfill several criteria: (1) widespread distribution throughout the targeted organism group, (2) high degree of conservation allowing for universal PCR amplification, (3) existence of variable regions allowing for the design of discriminating probes and (4) none or low rate of horizontal gene transfer.

The most commonly employed phylogenetic marker for the detection of microorganisms is the 16S rRNA gene. rRNAs are particularly suitable for species identification procedures as they occur universally, contain conserved as well as divergent regions and are highly abundant in bacterial cells. A further advantage of the 16S rRNA gene consists in the availability of large sequence and probe databases (www.arb-home.de, rdp.cme.msu.edu, greengenes.lbl.gov, http://www.microbialecology.net/probebase). The main limitation of the $16 \mathrm{~S}$ rRNA gene lies in its extremely high degree of conservation. In many cases (a notable example being various genera of Enterobacteriaceae) it is not possible to design even species-specific probes based on it.

Therefore, in order to augment discriminatory potential of short oligonucleotide microarrays, a scope of alternative, phylogenetic and functional marker genes has been suggested $[108,150]$. These include the $23 \mathrm{~S}$ rRNA gene, the rRNA intragenic 
spacer region, so-called house-keeping genes (e.g. grrB, $r p o B, \operatorname{rec} A$, atpD, groEL), virulence genes, antibiotic resistance genes and functional genes (e.g. $p m o A, a m o A$, nif $H$, nirK, nirS). Many of these have been successfully applied on various microarray platforms [21, 86, 171, 191]. The major limitation of these 'alternative' marker genes is the limited organism coverage of published sequence databases.

\section{3}

\section{Analysis and Quality Control Aspects}

Each step of microarray experiments needs to be optimized and validated, from array design and manufacture to data collection and analysis. Among critical technical parameters that need to be controlled are microarray surface chemistry, probe sequence, probe deposition process and hybridization conditions. The MicroArray Quality Control (MAQC) Consortium, an unprecedented, community-wide effort, spearheaded by US Food and Drug Administration scientists, recently addressed experimentally the key issues surrounding the reliability of DNA microarray data. They assessed the performance of seven microarray platforms in profiling the expression of two commercially available RNA sample types. Results were compared not only at different locations and between different microarray formats, but also in relation to three more traditional quantitative gene expression assays. The MAQC Consortium's main conclusions confirm that, with careful experimental design and appropriate data transformation and analysis, microarray data can indeed be reproducible and comparable among different formats and laboratories, irrespective of sample labeling format. The data also demonstrate that fold change results from microarray experiments correlate closely with results from assays like quantitative reverse transcription PCR [157].

However, different experimental setups require different validation approaches. Crucial aspect is array-to-array normalization [93, 159, 195]. Various methods for normalization have been suggested. For gene expression studies one approach is to determine a set of invariant genes for normalization [151, 177]. Another approach recommends replicating genes on the array and using this within-array replication for normalization [53-55]. Standard normalization protocols rely on the assumption that the majority of genes on the microarray are not differentially expressed between samples [194]. Jaeger et al. suggest including additional normalization genes on the small diagnostic microarrays and propose two strategies for selecting them from genome-wide microarray studies: data driven univariate selection of normalization genes or multivariate selection based on finding a balanced diagnostic signature [82].

In the case of diagnostic short oligonucleotide microarrays signals are usually normalized against positive controls. These positive controls are designed for conserved regions targeted gene, for the PCR primers used to amplify the targeted gene or against exogenously spiked DNA. Long oligonucleotide arrays can be normalized against general probes, targeting conserved regions of universal genes present in all bacteria [i.e. universal 16S probe(s)] or other housekeeping genes. 
Normalized signals are compared to arbitrary threshold values and the targeted microbes are rated as present or absent. For low-density short oligonucleotide arrays, the threshold values are ideally individual values, reflecting the hybridization potential of the individual probes. For long oligoarrays and high-density arrays with a highly redundant set of short oligonucleotides, it is possible to devise universal rules for calling a signal/set of signals present or absent.

\section{4}

\section{Applications of Microarray Technology in Microbial Diagnostics}

Microarray technology offers a great potential for answering many different experimental questions. The nature of the experimental question is the main issue that has to be taken into consideration when developing a new microarray platform. Depending on this question, there is an initial decision on the nature of probes and on the method for target labeling. This subsequently influences the selection of substrates and hybridization strategies. Some of the most common experimental questions for which microarray technology is used will be reviewed here.

\subsection{1}

\section{Gene Expression Studies}

The most widely used application of DNA microarrays is the study of transcriptional responses. Consequently, targets are derived from mRNA. Initial studies were limited to an organism or tissue of interest and provided insights in particular aspects of the organism's physiology $[68,152,167,199]$. For these studies, probes representing the genetic profile of organism or tissue of interest were used (e.g. clone libraries containing either genomic DNA or cDNA fragments). Recent developments of microarray technology enabled environmental monitoring of gene expression. Even though these studies are still limited to a few genes of interest, they can provide valuable information regarding the functionality of the whole microbial community [202].

\subsection{2}

\section{Comparative Genomic Hybridization (CGH)}

Traditional phylogenetic classification of bacteria to study evolutionary relatedness is based on the characterization of a limited number of genes, rRNA or signature sequences. However, owing to the acquisition of DNA through lateral gene transfer, the differences between closely related bacterial strains can be vast [42]. By contrast, whole-genome sequencing comparisons allow a multitude of genes to be compared. Unfortunately, whole-genome sequencing is currently too expensive to allow comparison of a large number of isolates of a species in a high-throughput scenario, as the global surveillance of infectious diseases requires. Therefore, as microbial genotyping is increasingly being used to track infectious diseases as they spread in human populations, another usage of microarrays has emerged. CGH permits assessing 
genetic similarities and differences between closely related organisms. This approach is an adaptation of array methods used in gene expression studies, but applied to total genomic DNA [97, 124]. CGH enables a 'bird's-eye view' of all the genes absent or present in a given genome compared to the reference genome on the microarray. Whole-genome comparisons typically identify sets of 'core genes', which are shared by all strains in a species, and 'accessory genes', which are present in one or more strains in a species and often result from gene acquisition. It is these differences that can often be used to identify genes and/or genetic islands related to 'gain-of-function traits' in pathogenic strains [42].

CGH approaches can be applied to further characterize strains to identify novel marker genes and chromosomal regions specific for given groups of isolates, thus providing better discrimination and additional information compared to classical genotyping methods [90]. However, ambiguities in the interpretation of the ratios of hybridization and cross-hybridizations to paralogous genes remain important limitations of the technique [181]. Solid statistical criteria for the absence/ presence of ORFs are still lacking as a result of the diversity of the microarray design approaches, affecting the meta-analysis of the data obtained by different investigators [83].

\subsection{3}

\section{Generic or Universal Microarrays}

Generic arrays have been proposed as an inexpensive alternative to sequencing. Using all possible combinations of an $n$-mer allows 'walking' at every position along a nucleotide sequence. This approach is currently limited by the complexity of the algorithm required to generate contigs (conversion of a listing of hybridized $n$-mers into a meaningful sequence). Also, if the sequence undergoing analysis contains a repeat region (the same sequence appearing more than once within the target molecule), the reconstruction diagram will have to display a corresponding number of branching points, leading to an ambiguous sequence. This type of array is the only one capable of detecting sequences that are lacking in large electronic libraries. In contrast, dedicated arrays are used for repetitive sequencing (resequencing) of the same target for detection of nucleotide polymorphisms or functional mutations.

Universal arrays refer to strategies that can provide target identification without any a priori sequence knowledge. This approach has been named the non-cognate hybridization system (see Chapter 4) [154]. By synthesizing all probes of a given length that can be generated by a combination of four nucleotides, microarrays could detect any single organism. Unfortunately, for generating realistic probe lengths (i.e. permitting unique sequence identification as well as adequate hybridization behavior), total number of permutations of the four nucleotides would yield to very large numbers of possible probes (i.e. $4^{13}=67108864$ probes for 13 mer nucleotides). Synthesis of such large microarrays is currently technically impossible. Furthermore, bioinformatics tools that would be necessary for microarray analysis of billons of probes are not yet available. Thus, reducing the probe set and the complexity of the 
analytical approach is warranted. Random reduction of the probe set to a smaller number of probes might result to the potential missing of sequences characteristic for given pathogens. An alternative would be the pruning of low informative probes, i.e. probes that have no targets in a collection of selected microorganisms. However, this approach yields ultimately to another cognate design, with the inherent limitations described above. Another way to reduce the probe set is to consider permutations of only two nucleotides. This divides the probe set by $2(n-2)$, where $n$ is the length of the probes. This microarray design is truly non-cognate and guarantees that no organism is a priori favored or missed. In analogy, Roth et al. have designed a universal microarray system combined with an enzymatic manipulation step that is capable of generating expression profiles from any organism without requiring a priori sequence-specific knowledge of transcript sequences [143].

Finally, we should mention here 'multi-purpose' arrays that contain probes for detecting a series of molecular barcodes. These molecular barcodes can be used as tags in various experimental conditions, for probing different targets under various experimental formats. These multi-purpose arrays serve only to quantitatively detect the presence of barcoded probes, whose specificity is determined by the user. Molecular inversion probe (MIP) technology was initially developed for the detection of SNPs in human genes [76]. MIP technology has been shown to work well for multiplexing, i.e. massive parallel processing (12000 MIPs in the same reaction tube) [77]. The power and versatility of MIP technology makes it perfectly suited for the identification and quantification of microbes. MIP's high sensitivity and specificity in detecting large numbers of SNPs $[76,77]$ should allow us to harness this technology to detect a large number of pathogens and to identify multiple infections in an individual sample. A MIP is comprised of genomic recognition sequences, common amplification sequences and a molecular barcode for each genotype assigned to a specific gene. This probe is a linear oligonucleotide with targetcomplementary sequences at the ends and a non-complementary linking segment in between [173].

\subsection{4}

\section{Microarrays for Sequence Analysis}

Generic or universal microarrays are only one of the many, technologically very diverse, microarray technologies available for sequence analysis.

Another possibility is an microarray containing a range of oligonucleotides covering a DNA sequence of interest, employing the so-called 'tiling strategy' [74]. Sequence analysis is performed by comparison of the hybridization patterns of the reference versus test sample. Such microarrays have been used for sequencing $[74,197]$, detection of SNPs [74, 98] and analysis of secondary structures [160]. Alternative detection methods have been suggested such as using a labeled common oligonucleotide primer that is extended to the site of the match or mismatch [106]. Publications have already started addressing the issue of automated interpretation of resequencing on microarrays [116]. 
Recent advances in high-density oligonucleotide arrays have enabled the development of high-throughput resequencing techniques. Resequencing arrays are designed to cover the entire genome by overlapping oligonucleotides. Multiple versions of each oligonucleotide are spotted on the array to represent the four possible base combinations (A, T, G and C) for each nucleotide position. To date, this technique has been applied to Bacillus anthracis with 56 strains being resequenced using a custom-designed resequencing array [203]. The same technique has also been used to track the evolution of the severe acute respiratory syndrome coronavirus [190]. Conversely, similar tiling-based resequencing has been employed for Staphylococcus speciation [37], genotyping [182] or detection of mutations conferring resistance to quinolone antimicrobials [38].

Finally, other bead-based arrays have been suggested for high-throughput sequencing-based approaches [29]. The latter approach resulted in a powerful highthroughput sequencing platform (Illumina-Solexa; www.illumina.com) that currently competes against the pyrosequencing method described by Margulies et al. [118].

\subsection{5}

\section{Microbial Diagnostic Microarrays (MDMs)}

MDMs are used for the simultaneous identification of microorganisms in clinical or environmental samples. Probes used for MDMs are usually oligonucleotides designed to be specific for a given strain, subspecies, species, genus or higher taxon. Classification and nomenclature of MDMs throughout the literature is not unanimous. According to their intended use, environmental MDMs [21, 110] and detection/ identification MDMs can be distinguished [78, 154]. The main difference between these two MDM types lies in their detection requirements.

Environmental MDMs are generally used to assess the whole microbial community structure or a subset of the microbial community in a particular environment. Therefore, reliable parallel detection of many different microorganisms and the potential for some level of quantification are required. Detection/identification MDMs are primarily used in clinical (medical, veterinary), food and biodefense microbiology. For this purpose, highly sensitive and specific detection of a few microorganisms in a complex community are required.

According to the nature of the marker gene, one can further distinguish phylogenetic [30, 110, 145] and functional MDMs, also referred to as functional gene arrays $[21,171,191]$.

There are two concepts for sensitivity of MDMs, both of them potentially posing a bottleneck to the detection of the targeted microbes. Absolute sensitivity refers to the amount of target DNA or number of target microbes required for successful detection. Absolute sensitivity reflects the hybridization capacity and detection sensitivity of the microarray platform used. Relative sensitivity, on the other hand, refers to the ratio of the targeted microbe within the entire microbial community analyzed. It is primarily due to low level non-specific background signal accumulation and to the fact that the amount of target DNA applicable in microarray hybridizations is limited. 
1.5

Further Developments and New Perspectives Regarding Array Sensitivity and Specificity

A promising approach to increase the sensitivity of a microarray assay is tyramide signal amplification [40]. Upon hybridization, this method relies on enzymatic amplification of the signal by employing horseradish peroxidase-mediated deposition of fluorochrome-labeled tyramides at the location of the probe. The relative sensitivity can be improved by limiting the labeling to very short, specific regions (Kostić et al. [206], and Refs. [14, 145]). High-density microarrays employing multiple $\mathrm{PM} / \mathrm{MM}$ probe sets for each targeted microbe also enable a significant improvement in relative sensitivity [30]. A novel method to analyze microarray data holds promise for a significant improvement in terms of relative sensitivity of MDMs [117].

The ultimate specificity of microarray technology depends on the discrimination between a fully complementary target and a non-target differing in only one single nucleotide. Various enzyme-assisted hybridization strategies (also used in SNP and resequencing assays $[52,98])$ are being applied because of their promise in strongly discriminating single mismatches located near the 3 '-end of microarray probes [34, 75, 101, 119, 135, 138, 145].

Isotope microarrays represent further development of the traditional phylogenetic MDMs, enabling linking phylogeny (community structure) to function. This approach employs 'double-labeled' targets, where the first radioactive labeling is substrate-mediated, and the second labeling is performed according to standard microarray protocols [1].

\section{6}

\section{Conclusions}

Development of microarray-based bacterial identification systems starting directly from the biological sample, without any enzymatic target amplification, would be most welcome [168]. During a single hybridization, arrays can integrate probes that provide microbial identification but also enclose large sets of discriminative epidemiological markers [31, 31, 70, 182, 183, 198], or contain probes to detect virulence or antimicrobial resistance determinants $[17,36,38,91,176]$. The high parallelism of microarray systems appears particularity adapted provided their design includes the following: (1) targeted universal gene(s), (2) simplified coupling and labeling protocols, (3) exquisite sensitivity, and (4) adapted analysis strategy.

\section{References}

1 Adamczyk, J., Hesselsoe, M., Iversen, N., Horn, M., Lehner, A., Nielsen, P.H., Schloter, M., Roslev, P. and Wagner, M. (2003) The isotope array, a new tool that employs substrate-mediated labeling of rRNA for determination of microbial community structure and function. Appl. Environ. Microbiol., 69, 6875-6887. 
2 Ahn, H.J., La, H.J. and Forney, L.J. (2006) System for determining the relative fitness of multiple bacterial populations without using selective markers. Appl. Environ. Microbiol., 72, 7383-7385.

3 Aitman, T.J. (2001) DNA microarrays in medical practice. BMJ, 323, 611-615.

4 Albert, T.J., Norton, J., Ott, M., Richmond, T., Nuwaysir, K., Nuwaysir, E.F., Stengele, K.P. and Green, R.D. (2003) Light-directed $5^{\prime} \rightarrow 3^{\prime}$ synthesis of complex oligonucleotide microarrays. Nucleic Acids Res., 31, e35.

5 Alizadeh, A.A., Eisen, M.B., Davis, R.E., Ma, C., Lossos, I.S., Rosenwald, A., Boldrick, J.C., Sabet, H., Tran, T., Yu, X., et al. (2000) Distinct types of diffuse large B-cell lymphoma identified by gene expression profiling. Nature, $\mathbf{4 0 3}$, 503-511.

6 Allawi, H.T. and SantaLucia, J. Jr, (1998) Nearest-neighbor thermodynamics of internal A.C mismatches in DNA: sequence dependence and $\mathrm{pH}$ effects. Biochemistry, 37, 9435-9444.

7 Anthony, R.M., Brown, T.J. and French, G.L. (2000) Rapid diagnosis of bacteremia by universal amplification of 23S ribosomal DNA followed by hybridization to an oligonucleotide array. J. Clin. Microbiol., 38, 781-788.

8 Aoyagi, K., Tatsuta, T., Nishigaki, M., Akimoto, S., Tanabe, C., Omoto, Y., Hayashi, S., Sakamoto, H., Sakamoto, M., Yoshida, T., et al. (2003) A faithful method for PCR-mediated global mRNA amplification and its integration into microarray analysis on laser-captured cells. Biochem. Biophys. Res. Commun., 300, 915-920.

9 Armitage, B.A. (2003) The impact of nucleic acid secondary structure on PNA hybridization. Drug Discov. Today, 8, 222-228.

10 Bae, J.W., Rhee, S.K., Nam, Y.D. and Park, Y.H. (2005) Generation of subspecies level-specific microbial diagnostic microarrays using genes amplified from subtractive suppression hybridization as microarray probes.

Nucleic Acids Res., 33, e113.

11 Bailly, X., Bena, G., Lenief, V., de Lajudie, P. and Avarre, J. C. (2006) Development of a lab-made microarray for analyzing the genetic diversity of nitrogen fixing symbionts Sinorhizobium meliloti and Sinorhizobium medicae. J. Microbiol. Methods, 67, 114-124.

12 Bains, W. and Smith, G.C. (1988) A novel method for nucleic acid sequence determination. J. Theor. Biol., 135, 303-307.

13 Baldeschwieler, J.D., Gamble, R.C. and Thierault, T.P. (1995) Method and apparatus for performing multiple sequential reactions on a matrix. WO9525116(19950314).

14 Ballmer, K., Korczak, B.M., Kuhnert, P., Slickers, P., Ehricht, R. and Hachler, H., (2007) Fast DNA serotyping of Escherichia coli by use of an oligonucleotide microarray. J. Clin. Microbiol., 45, 370-379.

15 Barczak, A., Rodriguez, M.W., Hanspers, K., Koth, L.L., Tai, Y.C., Bolstad, B.M., Speed, T.P. and Erle, D.J. (2003) Spotted long oligonucleotide arrays for human gene expression analysis. Genome Res., 13, 1775-1785.

16 Bavykin, S.G., Akowski, J.P., Zakhariev, V.M., Barsky, V.E., Perov, A.N. and Mirzabekov, A.D. (2001) Portable system for microbial sample preparation and oligonucleotide microarray analysis. Appl. Environ. Microbiol., 67, 922-928.

17 Bekal, S., Brousseau, R., Masson, L., Prefontaine, G., Fairbrother, J. and Harel, J. (2003) Rapid identification of Escherichia coli pathotypes by virulence gene detection with DNA microarrays. J. Clin. Microbiol., 41, 2113-2125.

18 Blanchard, A.P. and Friend, S.H. (1999) Cheap DNA arrays - it's not all smoke and mirrors. Nat. Biotechnol., 17, 953.

19 Blanchard, A.P., Kaiser, R.J. and Hood, L.E. (1996) High-density oligonucleotide arrays. Biosens. Bioelectron., 11, 687-690.

20 Bo, T. and Jonassen, I. (2002) New feature subset selection procedures for 
classification of expression profiles. Genome Biol., 3, RESEARCH0017.

21 Bodrossy, L. (2003) Diagnostic oligonucleotide microarrays for microbiology, in A Beginner's Guide to Microarrays, (ed. E.M. Blalock,), Kluwer, New York, pp. 566-582.

22 Bodrossy, L. and Sessitsch, A. (2004) Oligonucleotide microarrays in microbial diagnostics. Curr. Opin. Microbiol., 7 , 245-254.

23 Bodrossy, L., Stralis-Pavese, N., Konrad-Koszler, M., Weilharter, A., Reichenauer, T.G., Schofer, D. and Sessitsch, A. (2006) mRNA-based parallel detection of active methanotroph populations by use of a diagnostic microarray. Appl. Environ. Microbiol., 72, 1672-1676.

24 Bodrossy, L., Stralis-Pavese, N., Murrell, J.C., Radajewski, S., Weilharter, A. and Sessitsch, A. (2003) Development and validation of a diagnostic microbial microarray for methanotrophs. Environ. Microbiol., 5, 566-582.

25 Boldrick, J.C., Alizadeh, A.A., Diehn, M., Dudoit, S., Liu, C.L., Belcher, C.E., Botstein, D., Staudt, L.M., Brown, P.O. and Relman, D.A. (2002) Stereotyped and specific gene expression programs in human innate immune responses to bacteria. Proc. Natl Acad. Sci. USA, 99, 972-977.

26 Borucki, M.K., Krug, M.J., Muraoka, W.T. and Call, D.R. (2003) Discrimination among Listeria monocytogenes isolates using a mixed genome DNA microarray. Vet. Microbiol., 92, 351-362.

27 Borucki, M.K., Reynolds, J., Call, D.R., Ward, T.J., Page, B. and Kadushin, J. (2005) Suspension microarray with dendrimer signal amplification allows direct and high-throughput subtyping of Listeria monocytogenes from genomic DNA. J. Clin. Microbiol., 43, 3255-3259.

28 Brennan, T.M. and Heinecker, $\mathrm{H}$. (1995) Methods and compositions for determining the sequence of nucleic acids. 5,474,796 (US 5403708).

29 Brenner, S., Johnson, M., Bridgham, J., Golda, G., Lloyd, D.H., Johnson, D., Luo, S., McCurdy, S., Foy, M., Ewan, M., et al. (2000) Gene expression analysis by massively parallel signature sequencing (MPSS) on microbead arrays. Nat. Biotechnol., 18, 630-634.

30 Brodie, E.L., DeSantis, T.Z., Joyner, D.C., Baek, S.M., Larsen, J.T., Andersen, G.L., Hazen, T.C., Richardson, P.M., Herman, D.J., Tokunaga, T.K., et al. (2006) Application of a high-density oligonucleotide microarray approach to study bacterial population dynamics during uranium reduction and reoxidation. Appl. Environ. Microbiol., 72, 6288-6298.

31 Call, D.R., Bakko, M.K., Krug, M.J. and Roberts, M.C. (2003) Identifying antimicrobial resistance genes with DNA microarrays. Antimicrob. Agents Chemother., 47, 3290-3295.

32 Call, D.R., Borucki, M.K. and Loge, F.J. (2003) Detection of bacterial pathogens in environmental samples using DNA microarrays. J. Microbiol. Methods, 53, 235-243.

33 Case-Green, S.C. and Southern, E.M. (1994) Studies on the base pairing properties of deoxyinosine by solid phase hybridization to oligonucleotides. Nucleic Acids Res., 22, 131-136.

34 Cassat, J.E., Dunman, P.M., McAleese, F., Murphy, E., Projan, S.J. and Smeltzer, M.S. (2005) Comparative genomics of Staphylococcus aureus musculoskeletal isolates. J. Bacteriol., 187, 576-592.

35 Charbonnier, Y., Gettler, B.M., Francois, P., Bento, M., Renzoni, A., Vaudaux, P., Schlegel, W. and Schrenzel, J. (2005) A generic approach for the design of whole-genome oligoarrays, validated for genomotyping, deletion mapping and gene expression analysis on Staphylococcus aureus. BMC Genomics, 6, 95.

36 Chizhikov, V., Rasooly, A., Chumakov, K. and Levy, D.D. (2001) Microarray 
analysis of microbial virulence factors. Appl. Environ. Microbiol., 67, 3258-3263.

37 Couzinet, S., Jay, C., Barras, C., Vachon, R., Vernet, G., Ninet, B., Jan, I., Minazio, M.A., Francois, P., Lew, D., et al. (2005) High-density DNA probe arrays for identification of staphylococci to the species level. J. Microbiol. Methods, 61, 201-208.

38 Couzinet, S., Yugueros, J., Barras, C., Visomblin, N., Francois, P., Lacroix, B., Vernet, G., Lew, D., Troesch, A., Schrenzel, J., et al. (2005) Evaluation of a high-density oligonucleotide array for characterization of $g r l A, g r l B$, gyrA and gyrB mutations in fluoroquinolone resistant Staphylococcus aureus isolates. J. Microbiol. Methods, 60, 275-279.

39 Debouck, C. and Goodfellow, P.N. (1999) DNA microarrays in drug discovery and development. Nat. Genet., 21, 48-50.

40 Denef, V.J., Park, J., Rodrigues, J.L., Tsoi, T.V., Hashsham, S.A. and Tiedje, J.M. (2003) Validation of a more sensitive method for using spotted oligonucleotide DNA microarrays for functional genomics studies on bacterial communities. Environ. Microbiol., 5, 933-943.

41 Diehl, F., Grahlmann, S., Beier, M. and Hoheisel, J.D. (2001) Manufacturing DNA microarrays of high spot homogeneity and reduced background signal. Nucleic Acids Res., 29, e38.

42 Dorrell, N., Hinchliffe, S.J. and Wren, B.W. (2005) Comparative phylogenomics of pathogenic bacteria by microarray analysis. Curr. Opin. Microbiol., 8, 620-626.

43 Drmanac, R. and Crkvenjakov, R. (1999) Method of sequencing of genomes by hybridization of oligonucleotide probes US1991000723712 (US5202231).

44 Drmanac, R. and Drmanac, S. (1999) cDNA screening by array hybridization. Methods Enzymol., 303, 165-78, 165-178.

45 Drmanac, R., Drmanac, S., Strezoska, Z., Paunesku, T., Labat, I., Zeremski, M., Snoddy, J., Funkhouser, W.K., Koop, B. and Hood, L. (1993) DNA sequence determination by hybridization: a strategy for efficient large-scale sequencing.

Science, 260, 1649-1652.

46 Drmanac, S., Kita, D., Labat, I., Hauser, B., Schmidt, C., Burczak, J.D. and Drmanac, R. (1998) Accurate sequencing by hybridization for DNA diagnostics and individual genomics. Nat. Biotechnol., 16, 54-58.

47 Dunbar, S.A., Vander Zee, C.A., Oliver, K.G., Karem, K.L. and Jacobson, J.W. (2003) Quantitative, multiplexed detection of bacterial pathogens: DNA and protein applications of the Luminex LabMAP system. J. Microbiol. Methods, 53, 245-252.

48 Duveneck, G.L., Bopp, M.A., Ehrat, M., Balet, L.P., Haiml, M., Keller, U., Marowsky, G. and Soria, S. (2003) Two-photon fluorescence excitation of macroscopic areas on planar waveguides. Biosens. Bioelectron., 18, 503-510.

49 Epstein, J.R., Ferguson, J.A., Lee, K.H. and Walt, D.R. (2003) Combinatorial decoding: an approach for universal DNA array fabrication. J. Am. Chem. Soc., 125, 13753-13759.

50 Epstein, J.R., Leung, A.P., Lee, K.H. and Walt, D.R. (2003) High-density, microsphere-based fiber optic DNA microarrays. Biosens. Bioelectron., 18, 541-546.

51 Epstein, J.R. and Walt, D.R. (2003) Fluorescence-based fibre optic arrays: a universal platform for sensing. Chem. Soc. Rev., 32, 203-214.

52 Ericsson, O., Sivertsson, A., Lundeberg, J. and Ahmadian, A. (2003) Microarraybased resequencing by apyrase-mediated allele-specific extension. Electrophoresis, 24, 3330-3338.

53 Fan, J., Chen, Y., Chan, H.M., Tam, P.K. and Ren, Y. (2005) Removing intensity effects and identifying significant genes for Affymetrix arrays in macrophage migration inhibitory factor-suppressed neuroblastoma cells. Proc. Natl Acad. Sci. USA, 102, 17751-17756. 
54 Fan, J., Peng, H. and Huang, T. (2005) Semilinear high-dimensional model for normalization of microarray data: a theoretical analysis and partial consistency (with discussion). J. Am. Statist. Ass., 100, 781-813.

55 Fan, J., Tam, P., Woude, G.V. and Ren, Y. (2004) Normalization and analysis of cDNA microarrays using within-array replications applied to neuroblastoma cell response to a cytokine. Proc. Natl Acad. Sci. USA, 101, 1135-1140.

56 Fan, J.B., Chen, X., Halushka, M.K., Berno, A., Huang, X., Ryder, T., Lipshutz, R.J., Lockhart, D.J. and Chakravarti, A. (2000) Parallel genotyping of human SNPs using generic highdensity oligonucleotide tag arrays. Genome Res., 10, 853-860.

57 Ferguson, J.A., Steemers, F.J. and Walt, D.R. (2000) High-density fiber-optic DNA random microsphere array. Anal. Chem., 72, 5618-5624.

58 Fodor, S.P., Rava, R.P., Huang, X.C., Pease, A.C., Holmes, C.P. and Adams, C.L. (1993) Multiplexed biochemical assays with biological chips. Nature, 364, 555-556.

59 Fodor, S.P., Read, J.L., Pirrung, M.C., Stryer, L., Lu, A.T. and Solas, D. (1991) Light-directed, spatially addressable parallel chemical synthesis. Science, 251, 767-773.

60 Francois, P., Bento, M., Vaudaux, P. and Schrenzel, J. (2003) Comparison of fluorescence and resonance light scattering for highly sensitive microarray detection of bacterial pathogens. J. Microbiol. Methods, 55, 755-762.

61 Francois, P., Charbonnier, Y., Jaquet, J., Utinger, D., Bento, M., Lew, D.P., Kresbach, G., Schlegel, W. and Schrenzel, J. (2005) Rapid Bacterial identification using evanescent waveguide oligonucleotide microarray classification. J. Microbiol. Methods, 65, 390-403.

62 Francois, P., Garzoni, C., Bento, M. and Schrenzel, J. (2007) Comparison of amplification methods for transcriptomic analyses of low abundance prokaryotic RNA sources. J. Microbiol. Methods, 68, 385-391.

63 Franke-Whittle, I.H., Klammer, S.H., Mayrhofer, S. and Insam, H. (2006) Comparison of different labeling methods for the production of labeled target DNA for microarray hybridization. J. Microbiol. Methods, 65, 117-126.

64 Fredericks, D.N. and Relman, D.A. (1996) Sequence-based identification of microbial pathogens: a reconsideration of Koch's postulates. Clin. Microbiol. Rev., 9, 18-33.

65 Garaizar, J., Rementeria, A. and Porwollik, S. (2006) DNA microarray technology: a new tool for the epidemiological typing of bacterial pathogens? FEMS Immunol. Med. Microbiol., 47, 178-189.

66 Garzoni, C., Francois, P., Couzinet, S., Tapparel, C., Charbonnier, Y., Huyghe, A., Renzoni, A., Lucchini, S., Lew, D.P., Vaudaux, P., Kelley, W.L. and Schrenzel, J. (2007) A global view of Staphylococcus aureus whole genome expression upon internalization in human epithelial cells. BMC Genomics, 8, 171.

67 Gasch, A.P., Spellman, P.T., Kao, C.M., Carmel-Harel, O., Eisen, M.B., Storz, G., Botstein, D. and Brown, P.O. (2000) Genomic expression programs in the response of yeast cells to environmental changes. Mol. Biol. Cell, 11, 4241-4257.

68 Gill, R.T., Katsoulakis, E., Schmitt, W., Taroncher-Oldenburg, G., Misra, J. and Stephanopoulos, G. (2002) Genome-wide dynamic transcriptional profiling of the light-to-dark transition in Synechocystis sp. strain PCC 6803. J. Bacteriol., 184, 3671-3681.

69 Gillepsie, D. and Spiegelman, S.A. (1965) A quantitative assay for DNA-RNA hybrids with DNA immobilized on a membrane. J. Mol. Biol., 12, 829-842.

70 Gingeras, T.R., Ghandour, G., Wang, E., Berno, A., Small, P.M., Drobniewski, F., Alland, D., Desmond, E., Holodniy, M. 
and Drenkow, J. (1998) Simultaneous genotyping and species identification using hybridization pattern recognition analysis of generic Mycobacterium DNA arrays. Genome Res., 8, 435-448.

71 Golub, T.R., Slonim, D.K., Tamayo, P., Huard, C., Gaasenbeek, M., Mesirov, J.P., Coller, H., Loh, M.L., Downing, J.R., Caligiuri, M.A., et al. (1999) Molecular classification of cancer: class discovery and class prediction by gene expression monitoring. Science, 286, 531-537.

72 Grifantini, R., Bartolini, E., Muzzi, A., Draghi, M., Frigimelica, E., Berger, J., Ratti, G., Petracca, R., Galli, G., Agnusdei, M., et al. (2002) Previously unrecognized vaccine candidates against group B meningococcus identified by DNA microarrays. Nat. Biotechnol., 20, 914-921.

73 Guschin, D., Yershov, G., Zaslavsky, A., Gemmell, A., Shick, V., Proudnikov, D., Arenkov, P. and Mirzabekov, A. (1997) Manual manufacturing of oligonucleotide, DNA, and protein microchips. Anal. Biochem., 250, 203-211.

74 Hacia, J.G. (1999) Resequencing and mutational analysis using oligonucleotide microarrays. Nat. Genet., 21, 42-47.

75 Halperin, A., Buhot, A. and Zhulina, E.B. (2005) Brush effects on DNA chips: thermodynamics, kinetics, and design guidelines. Biophys. J., 89, 796-811.

76 Hardenbol, P., Baner, J., Jain, M., Nilsson, M., Namsaraev, E.A., Karlin-Neumann, G.A., Fakhrai-Rad, H., Ronaghi, M., Willis, T.D., Landegren, U., et al. (2003) Multiplexed genotyping with sequence-tagged molecular inversion probes. Nat. Biotechnol., 21, 673-678.

77 Hardenbol, P., Yu, F., Belmont, J., Mackenzie, J., Bruckner, C., Brundage, T., Boudreau, A., Chow, S., Eberle, J., Erbilgin, A., et al. (2005) Highly multiplexed molecular inversion probe genotyping: over 10000 targeted SNPs genotyped in a single tube assay. Genome Res., 15, 269-275.
78 Hashsham, S.A., Wick, L.M., Rouillard, J.M., Gulari, E. and Tiedje, J.M. (2004) Potential of DNA microarrays for developing parallel detection tools (PDTs) for microorganisms relevant to biodefense and related research needs. Biosens. Bioelectron., 20, 668-683.

79 Hessner, M.J., Meyer, L., Tackes, J., Muheisen, S. and Wang, X. (2004) Immobilized probe and glass surface chemistry as variables in microarray fabrication. BMC Genomics, 5, 53.

80 Holzman, T. and Kolker, E. (2004) Statistical analysis of global gene expression data: some practical considerations. Curr. Opin. Biotechnol., 15, 52-57.

81 Hughes, T.R., Mao, M., Jones, A.R., Burchard, J., Marton, M.J., Shannon, K.W., Ziman, M., Meyer, M.R., Kobayashi, S., Dai, H., et al. (2001) Expression profiling using microarrays fabricated by an ink-jet oligonucleotide synthesizer. Nat. Biotechnol., 19, 342-347.

82 Jaeger, J. and Spang, R. (2006) Selecting normalization genes for small diagnostic microarrays. $B M C$ Bioinformatics, 7, 388.

83 Joyce, E.A., Chan, K., Salama, N.R. and Falkow, S. (2002) Redefining bacterial populations: a post-genomic reformation. Nat. Rev. Genet., 3, 462-473.

84 Kafatos, F.C., Jones, C.W. and Efstratiadis, A. (1979) Determination of nucleic acid sequence homologies and relative concentrations by a dot hybridization procedure. Nucleic Acids Res., 7, 1541-1552.

85 Kajiyama, T., Miyahara, Y., Kricka, L.J., Wilding, P., Graves, D.J., Surrey, S. and Fortina, P. (2003) Genotyping on a thermal gradient DNA chip. Genome Res., 13, 467-475.

86 Kakinuma, K., Fukushima, M. and Kawaguchi, R. (2003) Detection and identification of Escherichia coli, Shigella, and Salmonella by microarrays using the gyrB gene. Biotechnol. Bioeng., 83, 721-728. 
87 Kelly, J.J., Chernov, B.K., Tovstanovsky, I., Mirzabekov, A.D. and Bavykin, S.G. (2002) Radical-generating coordination complexes as tools for rapid and effective fragmentation and fluorescent labeling of nucleic acids for microchip hybridization. Anal. Biochem., 311, 103-118.

88 Kessler, N., Ferraris, O., Palmer, K., Marsh, W. and Steel, A. (2004) Use of the DNA flow-thru chip, a three-dimensional biochip, for typing and subtyping of influenza viruses. J. Clin. Microbiol., 42, 2173-2185.

89 Knight, J. (2001) When the chips are down. Nature, 410, 860-861.

90 Koessler, T., Francois, P., Charbonnier, Y., Huyghe, A., Bento, M., Dharan, S., Renzi, G., Lew, D., Harbarth, S., Pittet, D., et al. (2006) Use of oligoarrays for characterization of community-onset methicillin-resistant Staphylococcus aureus. J. Clin. Microbiol., 44, 1040-1048.

91 Korczak, B., Frey, J., Schrenzel, J., Pluschke, G., Pfister, R., Ehricht, R. and Kuhnert, P. (2005) Use of diagnostic microarrays for determination of virulence gene patterns of Escherichia coli $\mathrm{K} 1$, a major cause of neonatal meningitis. J. Clin. Microbiol., 43, 1024-1031.

92 Kothapalli, R., Yoder, S.J., Mane, S. and Loughran, T.P. Jr (2002) Microarray results: how accurate are they? $B M C$ Bioinformatics, 3, 22.

93 Kroll, T.C. and Wolfl, S. (2002) Ranking: a closer look on globalization methods for normalization of gene expression arrays. Nucleic Acids Res., 30, e50.

$94 \mathrm{Li}$, J., Pankratz, M. and Johnson, J.A. (2002) Differential gene expression patterns revealed by oligonucleotide versus long cDNA arrays. Toxicol. Sci., 69, 383-390.

95 Li, W. (2005) How many genes are needed for early detection of breast cancer, based on gene expression patterns in peripheral blood cells? Breast Cancer Res, 7, e5.

96 Lima, W.F., Monia, B.P., Ecker, D.J. and Freier, S.M. (1992) Implication of RNA structure on antisense oligonucleotide hybridization kinetics. Biochemistry, 31, 12055-12061.

97 Lindroos, H.L., Mira, A., Repsilber, D., Vinnere, O., Naslund, K., Dehio, M., Dehio, C. and Andersson, S.G. (2005) Characterization of the genome composition of Bartonella koehlerae by microarray comparative genomic hybridization profiling. J. Bacteriol., 187, 6155-6165.

98 Lindroos, K., Liljedahl, U., Raitio, M. and Syvanen, A.C. (2001) Minisequencing on oligonucleotide microarrays: comparison of immobilization chemistries. Nucleic Acids Res., 29, e69.

99 Lindroos, K., Sigurdsson, S., Johansson, K., Ronnblom, L. and Syvanen, A.C. (2002) Multiplex SNP genotyping in pooled DNA samples by a four-colour microarray system. Nucleic Acids Res., 30, e70.

100 Lipshutz, R.J., Fodor, S.P., Gingeras, T.R. and Lockhart, D.J. (1999) High density synthetic oligonucleotide arrays. Nat. Genet., 21, 20-24.

101 Lipshutz, R.J., Morris, D., Chee, M., Hubbell, E., Kozal, M.J., Shah, N., Shen, N., Yang, R. and Fodor, S.P. (1995) Using oligonucleotide probe arrays to access genetic diversity. Biotechniques, 19, 442-447.

102 Liu, M., Popper, S.J., Rubins, K.H. and Relman, D.A. (2006) Early days: genomics and human responses to infection. Curr. Opin. Microbiol., 9, 312-319.

103 Liu, W.T., Guo, H. and Wu, J.H. (2007) Effects of target length on the hybridization efficiency and specificity of rRNA-based oligonucleotide microarrays. Appl. Environ. Microbiol., 73, 73-82.

104 Liu, W.T., Mirzabekov, A.D. and Stahl, D.A. (2001) Optimization of an oligonucleotide microchip for microbial identification studies: a non-equilibrium dissociation approach. Environ. Microbiol., 3, 619-629.

105 Lockhart, D.J., Dong, H., Byrne, M.C., Follettie, M.T., Gallo, M.V., Chee, M.S., Mittmann, M., Wang, C., Kobayashi, M., 
Horton, H., et al. (1996) Expression monitoring by hybridization to highdensity oligonucleotide arrays. Nat. Biotechnol., 14, 1675-1680.

106 Lodes, M.J., Suciu, D., Elliott, M., Stover, A.G., Ross, M., Caraballo, M., Dix, K., Crye, J., Webby, R.J., Lyon, W.J., et al. (2006) Use of semiconductor-based oligonucleotide microarrays for influenza a virus subtype identification and sequencing. J. Clin. Microbiol., 44, 1209-1218.

107 Loge, F.J., Thompson, D.E. and Call, D.R. (2002) PCR detection of specific pathogens in water: a risk-based analysis. Environ. Sci. Technol., 36, 2754-2759.

108 Loy, A. and Bodrossy, L. (2006) Highly parallel microbial diagnostics using oligonucleotide microarrays. Clin. Chim. Acta, 363, 106-119.

109 Loy, A., Lehner, A., Lee, N., Adamczyk, J., Meier, H., Ernst, J., Schleifer, K.H. and Wagner, M. (2002) Oligonucleotide microarray for 16S rRNA gene-based detection of all recognized lineages of sulfate-reducing prokaryotes in the environment. Appl. Environ. Microbiol., 68, 5064-5081.

110 Loy, A., Schulz, C., Lucker, S., Schopfer-Wendels, A., Stoecker, K., Baranyi, C., Lehner, A. and Wagner, M. (2005) 16S rRNA gene-based oligonucleotide microarray for environmental monitoring of the betaproteobacterial order 'Rhodocyclales'. Appl. Environ. Microbiol., 71, 1373-1386.

111 Lucchini, S., Liu, H., Jin, Q., Hinton, J.C. and Yu, J. (2005) Transcriptional adaptation of Shigella flexneri during infection of macrophages and epithelial cells: insights into the strategies of a cytosolic bacterial pathogen. Infect. Immun., 73, 88-102.

112 Lucchini, S., Thompson, A. and Hinton, J.C. (2001) Microarrays for microbiologists. Microbiology, 147, 1403-1414.

113 Ludwig, W., Strunk, O., Westram, R., Richter, L., Meier, H., Yadhukumar,
Buchner, A., Lai, T., Steppi, S., Jobb, G., et al. (2004) ARB: a software environment for sequence data. Nucleic Acids Res., 32, 1363-1371.

114 Lynch, J.L., deSilva, C.J., Peeva, V.K. and Swanson, N.R. (2006) Comparison of commercial probe labeling kits for microarray: towards quality assurance and consistency of reactions. Anal. Biochem., 355, 224-231.

115 Macevicz, S.C. (1995) Nucleic acid sequence determination by multiple mixed oligonucleotide probes, US1988000261702 (US5002867).

116 Malanoski, G.J., Samore, M.H., Pefanis, A. and Karchmer, A.W. (1995) Staphylococcus aureus catheter-associated bacteremia Minimal effective therapy and unusual infectious complications associated with arterial sheath catheters. Arch. Intern. Med., 155, 1161-1166.

117 Marcelino, L.A., Backman, V., Donaldson, A., Steadman, C., Thompson, J.R., Preheim, S.P., Lien, C., Lim, E., Veneziano, D. and Polz, M.F. (2006) Accurately quantifying lowabundant targets amid similar sequences by revealing hidden correlations in oligonucleotide microarray data. Proc. Natl Acad. Sci. USA, 103, 13629-13634.

118 Margulies, M., Egholm, M., Altman, W.E., Attiya, S., Bader, J.S., Bemben, L.A., Berka, J., Braverman, M.S., Chen, Y.J., Chen, Z., et al. (2005) Genome sequencing in microfabricated highdensity picolitre reactors. Nature, 437 , 376-380.

119 Maskos, U. and Southern, E.M. (1993) A novel method for the parallel analysis of multiple mutations in multiple samples. Nucleic Acids Res., 21, 2269-2270.

120 Maskos, U. and Southern, E.M. (1993) A study of oligonucleotide reassociation using large arrays of oligonucleotides synthesised on a glass support. Nucleic Acids Res., 21, 4663-4669.

121 Matveeva, O.V., Shabalina, S.A., Nemtsov, V.A., Tsodikov, A.D., Gesteland, R.F. and Atkins, J.F. (2003) Thermodynamic 
calculations and statistical correlations for oligo-probes design. Nucleic Acids Res., 31, 4211-4217.

122 Mikulowska-Mennis, A., Taylor, T.B., Vishnu, P., Michie, S.A., Raja, R., Horner, N. and Kunitake, S.T. (2002) High-quality RNA from cells isolated by laser capture microdissection.

Biotechniques, 33, 176-179.

123 Mir, K.U. and Southern, E.M. (1999) Determining the influence of structure on hybridization using oligonucleotide arrays. Nat. Biotechnol., 17, 788-792.

124 Murray, A.E., Lies, D., Li, G., Nealson, K., Zhou, J. and Tiedje, J.M. (2001) DNA/DNA hybridization to microarrays reveals gene-specific differences between closely related microbial genomes. Proc. Natl Acad. Sci. USA, 98, 9853-9858.

125 Naef, F. and Magnasco, M.O. (2003) Solving the riddle of the bright mismatches: labeling and effective binding in oligonucleotide arrays. Phys. Rev. E, 68, 011906.

126 Nguyen, H.K. and Southern, E.M. (2000) Minimizing the secondary structure of DNA targets by incorporation of a modified deoxynucleoside: implications for nucleic acid analysis by hybridization. Nucleic Acids Res., 28, 3904-3909.

127 Pasternack, R.F. and Collings, P.J. (1995) Resonance light scattering: a new technique for studying chromophore aggregation. Science, 269, 935-939.

128 Pawlak, M., Schick, E., Bopp, M.A., Schneider, M.J., Oroszlan, P. and Ehrat, M. (2002) Zeptosens' protein microarrays: a novel high performance microarray platform for low abundance protein analysis. Proteomics., 2, 383-393.

129 Pease, A.C., Solas, D., Sullivan, E.J., Cronin, M.T., Holmes, C.P. and Fodor, S.P. (1994) Light-generated oligonucleotide arrays for rapid DNA sequence analysis. Proc. Natl Acad. Sci. USA, 91, 5022-5026.

130 Peplies, J., Glockner, F.O. and Amann, R. (2003) Optimization strategies for DNA microarray-based detection of bacteria with 16S rRNA-targeting oligonucleotide probes. Appl. Environ. Microbiol., 69, 1397-1407.

131 Perou, C.M., Sorlie, T., Eisen, M.B. Van de, R.M., Jeffrey, S. S., Rees, C. A., Pollack, J. R., Ross, D. T., Johnsen, H., Akslen, L. A., et al. (2000) Molecular portraits of human breast tumours. Nature, 406, 747-752.

132 Perreten, V., Vorlet-Fawer, L., Slickers, P., Ehricht, R., Kuhnert, P. and Frey, J. (2005)

Microarray-based detection of 90 antibiotic resistance genes of Grampositive bacteria. J. Clin. Microbiol., 43, 2291-2302.

133 Peterson, A.W., Heaton, R.J. and Georgiadis, R.M. (2001) The effect of surface probe density on DNA hybridization. Nucleic Acids Res., 29, 5163-5168.

134 Phimister, B. (1999) Chipping forecast: going global. Nat. Genet, 21, Suppl 1.

135 Porwollik, S., Frye, J., Florea, L.D., Blackmer, F. and McClelland, M. (2003) A non-redundant microarray of genes for two related bacteria. Nucleic Acids Res., 31, 1869-1876.

136 Pozhitkov, A., Chernov, B., Yershov, G. and Noble, P.A. (2005) Evaluation of gel-pad oligonucleotide microarray technology by using artificial neural networks. Appl. Environ. Microbiol., 71, 8663-8676.

137 Pozhitkov, A., Noble, P.A., Domazet-Loso, T., Nolte, A.W., Sonnenberg, R., Staehler, P., Beier, M. and Tautz, D. (2006) Tests of rRNA hybridization to microarrays suggest that hybridization characteristics of oligonucleotide probes for species discrimination cannot be predicted. Nucleic Acids Res., 34, e66.

138 Proudnikov, D. and Mirzabekov, A. (1996) Chemical methods of DNA and RNA fluorescent labeling. Nucleic Acids Res., 24, 4535-4542.

139 Puskas, L.G., Zvara, A., Hackler, L., Jr. and Van Hummelen, P. (2002) RNA amplification results in reproducible 
microarray data with slight ratio bias. Biotechniques, 32, 1330-1340.

140 Raman, R., Raguram, S., Venkataraman, G., Paulson, J.C. and Sasisekharan, R. (2005) Glycomics: an integrated systems approach to structure-function relationships of glycans. Nat. Methods, 2, 817-824.

141 Rhee, S.K., Liu, X., Wu, L., Chong, S.C., Wan, X. and Zhou, J. (2004) Detection of genes involved in biodegradation and biotransformation in microbial communities by using 50-mer oligonucleotide microarrays. Appl. Environ. Microbiol., 70, 4303-4317.

142 Rimour, S., Hill, D., Militon, C. and Peyret, P. (2005) GoArrays: highly dynamic and efficient microarray probe design. Bioinformatics., 21, 1094-1103.

143 Roth, F.P., Hughes, J.D., Estep, P.W. and Church, G.M. (1998) Finding DNA regulatory motifs within unaligned noncoding sequences clustered by whole-genome mRNA quantitation. Nat. Biotechnol., 16, 939-945.

144 Rudi, K., Flateland, S.L., Hanssen, J.F., Bengtsson, G. and Nissen, H. (2002) Development and evaluation of a $16 \mathrm{~S}$ ribosomal DNA array-based approach for describing complex microbial communities in ready-to-eat vegetable salads packed in a modified atmosphere. Appl. Environ. Microbiol., 68, 1146-1156.

145 Rudi, K., Treimo, J., Nissen, H. and Vegarud, G. (2003) Protocols for 16S rDNA array analyses of microbial communities by sequence-specific labeling of DNA probes. Scientific World Journal, 3, 578-584.

146 Salama, N., Guillemin, K., McDaniel, T.K., Sherlock, G., Tompkins, L. and Falkow, S. (2000) A whole-genome microarray reveals genetic diversity among Helicobacter pylori strains. Proc. Natl Acad. Sci. USA, 97, 14668-14673.

147 Sanguin, H., Herrera, A., Oger-Desfeux, C., Dechesne, A., Simonet, P., Navarro, E., Vogel, T.M., Moenne-Loccoz, Y., Nesme, X. and Grundmann, G.L.
(2006) Development and validation of a prototype 16S rRNA-based taxonomic microarray for Alphaproteobacteria. Environ. Microbiol., 8, 289-307.

148 SantaLucia, J. Jr (1998) A unified view of polymer, dumbbell, and oligonucleotide DNA nearest-neighbor thermodynamics. Proc. Natl Acad. Sci. USA, 95, 1460-1465.

149 SantaLucia, J.J., Allawi, H.T. and Seneviratne, P.A. (1996) Improved nearest-neighbor parameters for predicting DNA duplex stability. Biochemistry, 35, 3555-3562.

150 Santos, S.R. and Ochman, H. (2004) Identification and phylogenetic sorting of bacterial lineages with universally conserved genes and proteins. Environ. Microbiol., 6, 754-759.

151 Schadt, E.E., Li, C., Ellis, B. and Wong, W.H. (2001) Feature extraction and normalization algorithms for highdensity oligonucleotide gene expression array data. J. Cell Biochem. Suppl., 37, 120-125.

152 Schena, M., Shalon, D., Davis, R.W. and Brown, P.O. (1995) Quantitative monitoring of gene expression patterns with a complementary DNA microarray. Science, 270, 467-470.

153 Scherl, A., Francois, P., Charbonnier, Y., Deshusses, J.M., Koessler, T., Huyghe, A., Bento, M., Stahl-Zeng, J., Fischer, A., Masselot, A., et al. (2006) Exploring glycopeptide resistance in Staphylococcus aureus: a combined proteomics and transcriptomics approach for the identification of resistance-related markers. BMC Genomics, 7, 296.

154 Schrenzel, J. and Hibbs, J. (2003) Noncognate hybridization system (NCHS) 00/75377 A2(6,544,777).

155 Sergeev, N., Distler, M., Courtney, S., Al Khaldi, S.F., Volokhov, D., Chizhikov, V. and Rasooly, A. (2004) Multipathogen oligonucleotide microarray for environmental and biodefense applications. Biosens. Bioelectron., 20, 684-698. 
156 Shchepinov, M.S., Case-Green, S.C. and Southern, E.M. (1997) Steric factors influencing hybridization of nucleic acids to oligonucleotide arrays. Nucleic Acids Res., 25, 1155-1161.

157 Shi, L., Reid, L.H., Jones, W.D., Shippy, R., Warrington, J.A., Baker, S.C., Collins, P.J., De Longueville, F., Kawasaki, E.S., Lee, K.Y., et al. (2006) The MicroArray Quality Control (MAQC) project shows inter- and intraplatform reproducibility of gene expression measurements. Nat. Biotechnol., 24, 1151-1161.

158 Small, J., Call, D.R., Brockman, F.J., Straub, T.M. and Chandler, D.P. (2001) Direct detection of 16S rRNA in soil extracts by using oligonucleotide microarrays. Appl. Environ. Microbiol., 67, 4708-4716.

159 Smyth, G.K. and Speed, T. (2003) Normalization of cDNA microarray data. Methods, 31, 265-273.

160 Sohail, M., Akhtar, S. and Southern, E.M. (1999) The folding oflarge RNAs studied by hybridization to arrays of complementary oligonucleotides. RNA., 5, 646-655.

161 Southern, E.M. (1989) Analysing polynucleotide sequences 19891100 (PCT89/10977).

162 Southern, E.M. (1975) Detection of specific sequences among DNA fragments separated by gel electrophoresis. J. Mol. Biol., 98, 503-517.

163 Southern, E.M., Case-Green, S.C., Elder, J.K., Johnson, M., Mir, K.U., Wang, L. and Williams, J.C. (1994) Arrays of complementary oligonucleotides for analysing the hybridization behaviour of nucleic acids. Nucleic Acids Res., 22, 1368-1373.

164 Southern, E.M., Mir, K. and Shchepinov, M. (1999) Molecular interactions on microarrays. Nat. Genet., 21, 5-9.

165 Stenger, D.A., Andreadis, J.D., Vora, G.J. and Pancrazio, J.J. (2002) Potential applications of DNA microarrays in biodefense-related diagnostics.
Curr. Opin. Biotechnol., 13,

208-212.

166 Stimpson, D.I., Cooley, P.W., Knepper, S.M. and Wallace, D.B. (1998) Parallel production of oligonucleotide arrays using membranes and reagent jet printing. Biotechniques, 25 , 886-890.

167 Stowe-Evans, E.L., Ford, J. and Kehoe, D.M. (2004) Genomic DNA microarray analysis: identification of new genes regulated by light color in the cyanobacterium Fremyella diplosiphon. J. Bacteriol., 186, 4338-4349.

168 Straub, T.M. and Chandler, D.P. (2003) Towards a unified system for detecting waterborne pathogens. J. Microbiol. Methods, 53, 185-197.

169 Strezoska, Z., Paunesku, T., Radosavljevic, D., Labat, I., Drmanac, R. and Crkvenjakov, R. (1991) DNA sequencing by hybridization: bases read by a non-gel-based method. Proc. Natl Acad. Sci. USA, 88, 10089-10093.

170 Tamayo, P., Slonim, D., Mesirov, J., Zhu, Q., Kitareewan, S., Dmitrovsky, E., Lander, E.S. and Golub, T.R. (1999) Interpreting patterns of gene expression with self-organizing maps: methods and application to hematopoietic differentiation. Proc. Natl Acad. Sci. USA, 96, 2907-2912.

171 Taroncher-Oldenburg, G., Griner, E.M., Francis, C.A. and Ward, B.B. (2003) Oligonucleotide microarray for the study of functional gene diversity in the nitrogen cycle in the environment. Appl. Environ. Microbiol., 69, 1159-1171.

172 Taylor, S., Smith, S., Windle, B. and Guiseppi-Elie, A. (2003) Impact of surface chemistry and blocking strategies on DNA microarrays. Nucleic Acids Res., 31, e87.

173 Thiyagarajan, S., Karhanek, M., Akhras, M., Davis, R.W. and Pourmand, N. (2006) PathogenMIPer: a tool for the design of molecular inversion probes to detect multiple pathogens. $B M C$ Bioinformatics, 7, 500. 
174 Tiquia, S.M., Wu, L., Chong, S.C., Passovets, S., Xu, D., Xu, Y. and Zhou, J. (2004) Evaluation of 50-mer oligonucleotide arrays for detecting microbial populations in environmental samples. Biotechniques, 36, 664-665.

175 Treimo, J., Vegarud, G., Langsrud, T., Marki, S. and Rudi, K. (2006) Total bacterial and species-specific 16S rDNA micro-array quantification of complex samples. J. Appl. Microbiol., 100, 985-998.

176 Troesch, A., Nguyen, H., Miyada, C.G., Desvarenne, S., Gingeras, T.R., Kaplan, P.M., Cros, P. and Mabilat, C. (1999) Mycobacterium species identification and rifampin resistance testing with high-density DNA probe arrays. J. Clin. Microbiol., 37, 49-55.

177 Tseng, G.C., Oh, M.K., Rohlin, L., Liao, J.C. and Wong, W.H. (2001) Issues in cDNA microarray analysis: quality filtering, channel normalization, models of variations and assessment of gene effects. Nucleic Acids Res., 29, 2549-2557.

178 Urakawa, H., El Fantroussi, S., Smidt, H., Smoot, J.C., Tribou, E.H., Kelly, J.J., Noble, P.A. and Stahl, D.A. (2003) Optimization of single-base-pair mismatch discrimination in oligonucleotide microarrays. Appl. Environ. Microbiol., 69, 2848-2856.

179 Urakawa, H., Noble, P.A., El Fantroussi, S., Kelly, J.J. and Stahl, D.A. (2002) Single-base-pair discrimination of terminal mismatches by using oligonucleotide microarrays and neural network analyses. Appl. Environ. Microbiol., 68, 235-244.

180 Vainrub, A. and Pettitt, B.M. (2002) Coulomb blockage of hybridization in two-dimensional DNA arrays. Phys. Rev. E, 66, 041905.

181 van Bakel, H. and Holstege, F.C. (2004) In control: systematic assessment of microarray performance. EMBO Rep., 5, 964-969.

182 van Leeuwen, W.B., Jay, C., Snijders, S., Durin, N., Lacroix, B., Verbrugh, H.A., Enright, M.C., Troesch, A. and
Van Belkum, A. (2003) Multilocus sequence typing of Staphylococcus aureus with DNA array technology. J. Clin.

Microbiol., 41, 3323-3326.

183 Volokhov, D., Rasooly, A., Chumakov, K. and Chizhikov, V. (2002) Identification of listeria species by microarray-based assay. J. Clin. Microbiol., 40, 4720-4728.

184 Voordouw, G., Voordouw, J.K., Karkhoff-Schweizer, R.R., Fedorak, P.M. and Westlake, D.W. (1991) Reverse sample genome probing, a new technique for identification of bacteria in environmental samples by DNA hybridization, and its application to the identification of sulfate-reducing bacteria in oil field samples. Appl. Environ. Microbiol., 57, 3070-3078.

185 Vora, G.J., Meador, C.E., Stenger, D.A. and Andreadis, J.D. (2004) Nucleic acid amplification strategies for DNA microarray-based pathogen detection. Appl. Environ. Microbiol., 70, 3047-3054.

186 Wang, D., Coscoy, L., Zylberberg, M., Avila, P.C., Boushey, H.A., Ganem, D. and DeRisi, J.L. (2002) Microarray-based detection and genotyping of viral pathogens. Proc. Natl Acad. Sci. USA, 99, 15687-15692.

187 Wang, R.F., Beggs, M.L., Erickson, B.D. and Cerniglia, C.E. (2004) DNA microarray analysis of predominant human intestinal bacteria in fecal samples. Mol. Cell Probes, 18, 223-234.

188 Wilson, C.L., Pepper, S.D., Hey, Y. and Miller, C.J. (2004) Amplification protocols introduce systematic but reproducible errors into gene expression studies. Biotechniques, 36, 498-506.

189 Wilson, K.H., Wilson, W.J., Radosevich, J.L., DeSantis, T.Z., Viswanathan, V.S., Kuczmarski, T.A. and Andersen, G.L. (2002) High-density microarray of small-subunit ribosomal DNA probes. Appl. Environ. Microbiol., 68, 2535-2541.

190 Wong, C.W., Albert, T.J., Vega, V.B., Norton, J.E., Cutler, D.J., Richmond, T.A., 
Stanton, L.W., Liu, E.T. and Miller, L. D. (2004) Tracking the evolution of the SARS coronavirus using high-throughput, high-density resequencing arrays. Genome Res., 14, 398-405.

191 Wu, L., Thompson, D.K., Li, G., Hurt, R.A., Tiedje, J.M. and Zhou, J. (2001) Development and evaluation of functional gene arrays for detection of selected genes in the environment. Appl. Environ. Microbiol., 67, 5780-5790.

192 Wu, Y., de Kievit, P., Vahlkamp, L., Pijnenburg, D., Smit, M., Dankers, M., Melchers, D., Stax, M., Boender, P.J., Ingham, C., et al. (2004) Quantitative assessment of a novel flow-through porous microarray for the rapid analysis of gene expression profiles. Nucleic Acids Res., 32, e123.

193 Xiang, C.C., Chen, M., Ma, L., Phan, Q.N., Inman, J.M., Kozhich, O.A. and Brownstein, M.J. (2003) A new strategy to amplify degraded RNA from small tissue samples for microarray studies. Nucleic Acids Res., 31, e53.

194 Yang, Y.H., Dudoit, S., Luu, P., Lin, D.M., Peng, V., Ngai, J. and Speed, T.P. (2002) Normalization for cDNA microarray data: a robust composite method addressing single and multiple slide systematic variation. Nucleic Acids Res., 30, e15.

195 Yang, Y.H. and Speed, T. (2002) Design issues for cDNA microarray experiments. Nat. Rev. Genet., 3, 579-588.

196 Ye, R.W., Wang, T., Bedzyk, L. and Croker, K.M. (2001) Applications of DNA microarrays in microbial systems. J. Microbiol. Methods, 47, 257-272.

197 Yershov, G., Barsky, V., Belgovskiy, A., Kirillov, E., Kreindlin, E., Ivanov, I., Parinov, S., Guschin, D., Drobishev, A., Dubiley, S., et al. (1996) DNA analysis and diagnostics on oligonucleotide microchips. Proc. Natl Acad. Sci. USA, 93, 4913-4918.

198 Yue, H., Eastman, P.S., Wang, B.B., Minor, J., Doctolero, M.H., Nuttall, R.L.,
Stack, R., Becker, J.W., Montgomery, J.R., Vainer, M., et al. (2001) An evaluation of the performance of cDNA microarrays for detecting changes in global mRNA expression. Nucleic Acids Res., 29, e41.

199 Zaigler, A., Schuster, S.C. and Soppa, J. (2003) Construction and usage of a onefold-coverage shotgun DNA microarray to characterize the metabolism of the archaeon Haloferax volcanii. Mol. Microbiol., 48, 1089-1105.

200 Zammatteo, N., Jeanmart, L., Hamels, S., Courtois, S., Louette, P., Hevesi, L. and Remacle, J. (2000) Comparison between different strategies of covalent attachment of DNA to glass surfaces to build DNA microarrays. Anal. Biochem., 280, 143-150.

201 Zhang, L., Hurek, T. and Reinhold-Hurek, B. (2006) A nifH-based oligonucleotide microarray for functional diagnostics of nitrogen-fixing microorganisms. Microb. Ecol., 8, 1721-1735.

202 Zhou, J. and Thompson, D.K. (2002) Challenges in applying microarrays to environmental studies. Curr. Opin. Biotechnol., 13, 204-207.

203 Zwick, M.E., Mcafee, F., Cutler, D.J., Read, T.D., Ravel, J., Bowman, G.R., Galloway, D.R. and Mateczun, A. (2005) Microarray-based resequencing of multiple Bacillus anthracis isolates. Genome Biol., 6, R10.

204 Schena, M. (2005) Protein Microarrays, Jones \& Bartlett, Sudbury MA.

205 Talaat, A.M., Hunter, P. and Johnston, S.A. (2000) Genome-directed primers for selective labeling of bacterial transcripts for DNA microarray analysis. Nat Biotechnol., 18, 679-682.

206 Kostić, T., Weilharter, A., Rubino, S., Delogu, G., Uzzau, S., Rudi, K., Sessitsch, A. and Bodrossy, L. (2007) A microbial diagnostic microarray technique for the sensitive detection and identification of pathogenic bacteria in a background of non-pathogens. Analytical Biochemistry, 360, 244-254. 